\title{
SALITRE: O PRODUTO QUÍMICO ESTRATÉGICO NO PASSADO DO BRASIL
}

Luciano E. Faria ${ }^{a}, *,\left(\right.$ e Carlos A. L. Filgueiras ${ }^{\mathrm{b}}$

anstituto de Ciências Exatas, Centro Universitário Newton Paiva, 30494-060 Belo Horizonte - MG, Brasil

bDepartamento de Química, Universidade Federal de Minas Gerais, 31270-901 Belo Horizonte - MG, Brasil

Recebido em 02/09/2020; aceito em 13/11/2020; publicado na web em 15/12/2020

\begin{abstract}
SALTPETER: THE STRATEGIC CHEMICAL PRODUCT IN THE PAST OF BRAZIL. Saltpeter demanded for a long-time strategic attention in view of its importance in the form of gunpowder by the governments of many nations. The sources of this mineral in Brazil were almost always associated to the soil in caves, which was extracted because of a limited amount of that precious salt. The first references pointed out that saltpeter was first discovered in the São Francisco basin in regions of the south of the Captaincy of Bahia and in the north of Minas Gerais. Some historical documents show that the Serra do Baldim was the object of intensive mining activities of saltpeter from its caves and the product became the focus of conflicts and left scars on the walls of some limestone caverns.
\end{abstract}

Keywords: Saltpeter; natural nitrate mining; cave; mineral exploitation.

\section{INTRODUÇÃO}

O Salitre (ou como referem ainda os antigos autores, nitro), mineral constituído principalmente pelo composto inorgânico de fórmula $\mathrm{KNO}_{3}$, desempenhava um papel fundamental na defesa de um estado. Quando misturado com enxofre e carvão em proporções que poderiam variar entre nações, culturas ou formas de aplicação, a pólvora era o mais almejado produto do salitre. Por tal motivo, a descoberta, exploração e beneficiamento desse sal era fator estratégico e ponto determinante de inúmeras demandas políticas de grandes nações europeias nos séculos passados. No século XIX, a importância militar do salitre foi muito bem salientada em Portugal por Thomé Rodrigues Sobral (1759-1829), professor da Cadeira de Química da Universidade de Coimbra, em seu artigo no Jornal de Coimbra de 1816:

Quem sabe os usos importantes e extensos do salitre, conhece sem difficuldade que elle faz um artigo da primeira necessidade em todas as Nações. Com effeito, os meios de defeza de qualquer Nação segundo o systema actual da guerra são necessariamente ligados á existencia ou não existencia do mesmo sal. A Tropa mais bem disciplinada, os mais intrepidos Generaes, e os mais insignes na Sciencia Militar; o melhor, estado de fortificações e armamentos tudo he inutil sem salitre. Ora já se-vê que eu quero fallar da necessidede d'este sal para o fabrico da polvora, sem a qual toda a Nação deve renunciar á pertenção de deffender-se de qualquer outra que ouse inquietal-a e invadil-a. Coimbra sentio bem esta verdade no dia memorável 23 de Junho de 1808: dia da abençoada, pôsto que arriscada, revolução contra os Francezes, que se havião ja apoderado de grande parte das nossas praças, e por consequencia das nossas pólvoras e armamentos. Gritava-se por toda a parte ás armas; o valor e o patriotismo ião até o enthusiasmo: mas a falta de polvora era quase absoluta. Eu me vi inopinadamente encarregado pelas Authoridades constituidas de a fabricar, posso dizer sem meios, de um dia até o outro, se fosse possivel: e até posso accrescentar, quasi me achei sacrificado á impostura (por não dizer á perfídia) de quem quiz persuadir que no Laboratorio da

*e-mail: luemfa@hotmail.com
Universidade, onde por via e regra só se fabricão algumas libras para ensino, se podião diariamente fabricar muitas arrobas: ¿como pois tirar-me de tão apertada situação, $e$ desempenhar tão dificil, e ao mesmo tempo tão importante commissão que ao depois me veio á ser tão fatal? (Ella foi o motivo do incêndio das minhas casas e dos meus livros). ${ }^{l}$

No final desse texto, Sobral está narrando o episódio da invasão francesa a Portugal que afugentou toda a Corte para o Brasil em 1808, gerando diversas consequências (a maioria positivas) à então Colônia. Ao professor Sobral restaria a destruição de sua casa após a elogiada ação de produção de pólvora para os oficiais britânicos que davam apoio aos portugueses. Já os invasores franceses, em retaliação, destruíram a propriedade de Sobral nos arredores de Coimbra, dando fim a uma coleção de notas de investigações científicas e livros de sua biblioteca. ${ }^{2}$ Pela contribuição ao desenvolvimento e aperfeiçoamento do fabrico do explosivo em Portugal, Sobral obteve o título de "mestre da Pólvora", que ainda perdura em trabalhos e biografias atuais que o citam. ${ }^{3,4}$

Ainda no século XIX, em Portugal, a importância do salitre se demonstrava estratégica e fazia parte de memórias, relatórios, cartas régias e manuais de instrução emitidos por diversos filósofos naturais e gente da classe política. No Brasil o material ganhou as páginas, em versos e rimas, da "Descripção curiosa das Principaes producções, rios, e animaes do Brazil, principalmente da Capitania de Minas Geraes" que, redigido por Joaquim José Lisboa, ${ }^{5}$ descreve à sua musa as riquezas da província mineira:

Há certo monte, Marília,

Junto a comarca do Serro

Que tem em si prata e ferro,

Mesmo em cima do seu cume

E no Itacambiruçu ${ }^{A}$

junto à diamantina serra,

se faz extrair da terra

excelente pedra-ume

Há salitre em abundâncias, ${ }^{B}$

barro para louça, cal

E faz extrair da terra sal

N’alguns sítios do sertão 
A: rio diamantino; foi riquíssima de diamantes a serra que ele banha; junto a ela se tem extrahido muita quantidade de pedra-ume, e há por muitos sítios do Brasil; B: Há muita abundância de salitre em quase todo Brasil, e principalmente junto ao rio do Sono. Também há excelente barro para louça e dele temos usado no Brasil. ${ }^{6}$

Nota-se que o salitre, contado até mesmo em verso e prosa, era um produto químico de uso cotidiano e deveria ser tão comum e conhecido naquela época como hoje é conhecido o fósforo dos palitos ou mesmo o cloro (ou hipoclorito) da água sanitária. No entanto, diferentemente do que ocorreu nas Índias durante a época das Grandes Navegações Europeias ou, mais tardiamente, da descoberta de imensos depósitos de nitratos do conhecido 'Salitre do Chile', os depósitos do principal componente da pólvora no Brasil não ganharam tanta atenção. Como um produto mineral a ser extraído e beneficiado no Brasil, o salitre encontrava grandes concorrentes: o ouro, o diamante e demais pedras preciosas eram mais atraentes ao governo e aos mineradores pois davam retorno mais rápido aos investimentos nas 'indústrias' em campos gerais (localidades distantes) da Capitania portuguesa no Novo Mundo. Na colônia as fontes do salitre estavam sempre muito longe de seu local de consumo ou refinamento, ou seja, as grandes fábricas das cidades portuárias que permitiriam a utilização ou exportação do bem tão precioso.

Apesar de todas essas circunstâncias, era nos períodos mais conturbados por guerras e conflitos, que o governo português destacava especialistas na identificação de fontes de salitre por todas as capitanias brasileiras, sendo incumbido a naturalistas e administradores das comarcas que também indicassem aos governantes as corretas formas de extração, beneficiamento e escoamento do produto para as capitais ou fábricas de pólvora.

\section{EXPLORAÇÃO DO SALITRE - MIGRAÇÃO DO CONHECIMENTO DOS SERTÕES DA BAHIA PARA A BUSCA E EXTRAÇÃO MINERAL DE "NITREIRAS" EM MINAS GERAIS}

No Brasil, a história da descoberta e extração do salitre coincide com a história da conquista e da exploração dos Sertões de nosso país. O avanço populacional nas proximidades do litoral aumentava o interesse pelos 'desertões' do interior do continente das maiores capitanias. Esse fato ocorreu inicialmente na Bahia, principalmente na época em que Salvador exercia elevada importância política como capital da colônia entre 1549 até 1763 . Os ditos exploradores, denominados 'sertanejos', acumularam por décadas o conhecimento de rios, serras e montanhas que permitiriam o estabelecimento de rotas de navegação e a criação de estradas em direção ao interior do Brasil. Dessa forma, aos poucos se desenhavam as delimitações das capitanias banhadas pelo Rio São Francisco que contou também, na sua porção mais ao sul, com o avanço das Bandeiras que partiam de São Paulo. Entretanto, é certo que outro fator mais relevante e que não enxerga fronteiras, a geologia local, foi proeminente na descoberta das novas fontes minerais localizadas entre as capitanias da Bahia e de Minas Gerais.

Desde a época dos primeiros desbravadores, as feições geológicas ofereciam aos exploradores paisagens de formações quartzíticas (de composição química silícica, $\mathrm{SiO}_{2}$ ) e calcárias (carbonatos, $\mathrm{CO}_{3}^{-2}$ ) dos supergrupos geológicos do Espinhaço e São Francisco. Nos primeiros mapas coloniais essas formações são indicadas como serras, morros e montes, cujas localizações variavam não só entre as jurisdições das capitanias de Minas Gerais e Bahia, mas também à capitania de Pernambuco nas regiões próximas ao Rio São Francisco. Essa geologia sedimentar é também característica por oferecer grande número de cavidades naturais (grutas, lapas ou cavernas) que, de acordo com livros e manuais europeus sobre salitre e pólvora (contemporâneos às explorações naturalistas), eram ambientes propícios de serem naturais 'salitreiras' ou 'nitreiras' - ou ainda 'nitrateiras'.

O salitre das denominadas regiões do Sertão da Ressaca, ${ }^{7}$ no sul da Bahia e do norte de Minas Gerais, já havia sido descoberto em 1624 por Francisco Dias D’Ávila (1590-?) que

obteve permissão para assenhorear-se de mais 200 léguas de terra, desde o rio $S$. Francisco até o rio da Cachoeira, de rio a rio (...), as serras todas de Jacobina e a serra de Loisembá, e destas ditas serras para o sertão 100 léguas, e daí para a costa do mar outras cem léguas. ${ }^{8}$

A extração de salitre no final do século XVII e início do século XVIII é destacada pelo historiador Francisco Adolfo de Varnhagen (1816-1878) em seu livro "História Geral do Brazil" no qual indica:

\begin{abstract}
Outra industria a que então se quis dar impulso, foi a da extracção do salitre das nitreiras dos sertões da Bahia. Em 1694 fora o governador D. João de Lencastre mandado passar pessoalmente ás ditas nitreiras. Tres annos depois a casa da Torre se comprometteu a por annualmente na Caxoeira vinte mil quintaes de salitre; porém sem tardança se viu obrigada a rescindir o contracto, offerecendo sessenta mil cruzados á Coroa, a titulo de indemnisação, o que lhe foi acceito (1699), ordenando-se que se aperfeiçoassem as fabricas estabelecidas antes por Pedro Barboza Leal. Em 1702 vieram á Bahia, oitenta e nove surrões, que produziram mais de cento e setenta arrobas de salitre. Pouco depois explorou Gaspar dos Reis novas nitreiras no morro do Chapéo. Porém a final em 1706 resolveu a Corte que não se proseguisse mais nesses trabalhos, pois que o producto não cobria os gastos. ${ }^{9}$
\end{abstract}

De acordo com essas duas últimas citações, a rota que o produto beneficiado deveria tomar para abastecer o mercado soteropolitano fazia uso do "rio da Cachoeira" ou o porto "na Caxoeira". Trata-se atualmente do rio Paraguassú e sua divisa portuária na entrada da Baía de Todos os Santos - no que hoje é o município de Cachoeira.

A partir do século XVIII as referências históricas permitem a verdadeira localização do local de extração do salitre. De acordo com as "Memórias do Districto Diamantino da Comarca do Serro", ${ }^{10}$ escrito por Joaquim Felício dos Santos, o autor aponta que:

estava muito em voga a industria da mineração do salitre. $O$ descobrimento d'este mineral nos sertões da Bahia (Montes Altos), excitava os aventureiros, que sahirão a procural-o por toda a parte..$^{10}$

A localização dos 'Montes Altos' pode referir-se atualmente ao Parque Estadual homônimo e localizado entre as cidades baianas de Palmas de Monte Alto e de Sebastião das Laranjeiras, a uma distância média de $30 \mathrm{~km}$ ao norte da divisa com o estado de Minas Gerais. Contudo, os métodos cartográficos do século XVIII empregados para descrever o local não permitem a indicação dos pontos geográficos no mapa, ${ }^{11}$ fazendo com que a localização das serras e montanhas seja imprecisa. Dessa forma, a região citada pode ainda ser atribuída à seção triangular compreendida entre o Rio São Francisco e um de seus afluentes, o Rio Verde Grande, de acordo com a ilustração do mapa (Figura 1) das "Nitreiras dos Montes Altos (BA)". 
Dentre todas as formações geológicas entre Minas e Bahia, a Serra dos Montes Altos foi a que atraiu maior atenção dos exploradores dada sua abundância de salitre. Tal afirmação é apoiada em uma série de documentos cartográficos e desenhos que indicavam a "Planta Topográfica, e Prospetos da Serra dos Montes Altos"12 - com seus pontos de extração de salitre - e um mapa da "Planta chorografica da estrada de São Félix a Montes Altos". ${ }^{13}$ Esses dois mapas são assinados por José Antônio Caldas bem como o desenho de um prédio fortificado proposto para o beneficiamento do salitre e sua conversão em pólvora. Essa construção ainda existe na capital baiana e fica na Alameda dos Aflitos, sendo utilizada atualmente como Quartel do Comando Geral da Polícia Militar da Bahia. Na planta e perfis criados pelo mesmo datados de 1756, a legenda informa a seguinte nota: "Planta, profil, fachada e a metade do telhado em que se fabricou a polvora na Cidade da Bahia, esta ao pé do forte de S. Pedro". ${ }^{14}$ Esse prédio deveria ser o ponto final da longa estrada que levava o nitrato da serra até seu beneficiamento (Figura 2).

Um prédio de dimensões tão proeminentes deveria ter elevada necessidade de provisões e fornecimento de matéria prima. Isso leva a crer que a descoberta do salitre, seja no sul do território baiano ou norte do mineiro, deve ter feito com que grande parte do produto extraído e purificado tenha sido escoado para Salvador para a produção de pólvora (Figura 3).

No entanto, vale observar que nenhum dos documentos históricos abordados anteriormente indica a natureza das salitreiras de onde era extraído para ser purificado nas 'fábricas'. Fica a dúvida de que fosse extraído a céu aberto (como acontecia na Índia) ou em cavernas (como relatado em tratados europeus). Essa mesma questão foi formulada pelos naturalistas Spix e Martius, que descreveram os sertões no início do século XIX:

Descobriu-se na Serra dos Montes Altos grande quantidade de terra salitrosa, que estaria depositada na superfície e em grutas (de pedra calcária?), porém ainda não se explora seriamente isto provavelmente, por ser proibida a exportação do salitre do Brasil, e pela distância dos lugares onde existem as reais fábricas de pólvora - Rio de Janeiro, Vila Rica e Oeiras (essa última referente à cidade portuguesa). O Brasil é tão extraordinariamente rico nesse apreciado produto, que a libertação do comércio de salitre lhe traria grandes vantagens. ${ }^{15}$

Além de lançar dúvidas sobre a fonte do salitre, os alemães também desconhecem (em 1820) o beneficiamento de pólvora na 'Cidade da Bahia', à época já sem o título de capital da Colônia. Já os depósitos de salitre "na superfície" podem gerar estranheza aos químicos que analisam tal questão. O nitrato de potássio é extremamente solúvel em água, $33 \mathrm{~g} / 100 \mathrm{~mL} \mathrm{H}_{2} \mathrm{O}$ a $2{ }^{\circ} \mathrm{C}$, enquanto o nitrato de cálcio é 4 vezes mais solúvel sob as mesmas condições. Dessa forma qualquer acúmulo superficial desse mineral, exposto a chuvas, seria completamente dissolvido e escoado com as enxurradas. Assim, pode se deduzir que todo o nitrato disponível para mineração se encerrava em interiores de cavernas e lapas onde a água os concentrava e que de lá não poderiam ser carreados para nenhum outro lugar.

Contudo, nenhuma caverna no Parque Estadual Serra dos Montes Altos foi cadastrada até hoje, o que necessariamente não indica que não existam. Além disso, a serra não é formada por rochas carbonáticas (o calcário, $\mathrm{CaCO}_{3}$, ou a dolomita, $\mathrm{CaMg}\left[\mathrm{CO}_{3}\right]_{2}$ ), mais propícias à formação de grutas, cavernas e lapas. ${ }^{16}$

Ressalta-se que a documentação do século XVIII pesquisada não indica em nenhuma oportunidade que o salitre estivesse encerrado nos interiores de cavernas, o que leva a crer que o nome nitreira (ou nitrateiras) naturais já trouxesse no sentido, aplicado à época, o significado de ambiente subterrâneo propício à formação do nitro. A busca por salitre nesses terrenos propícios à formação de cavidades naturais de Minas Gerais e da Bahia parece ter sido mesmo uma

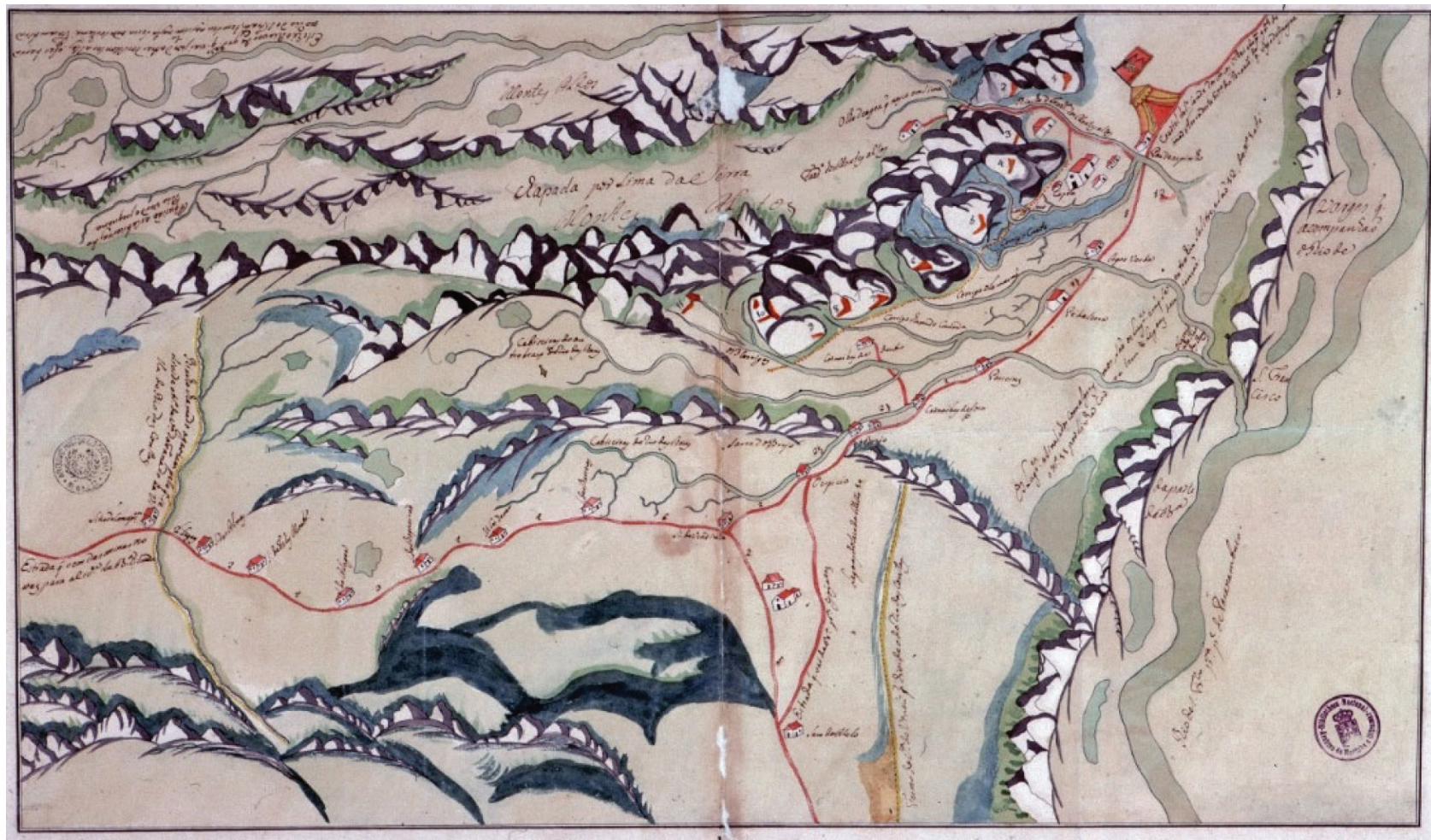

Figura 1. Mapa da indicação de Montes Altos situado entre o rio São Francisco (que se vê à direita de acordo com legenda logo acima do carimbo oficial) $e$ o rio Verde Grande indicado no topo da figura. De acordo com correto referencial geográfico; o ponto superior direito indica o local de abrigo do Conde dos Arcos; o Norte está na base da figura ${ }^{l l}$ 

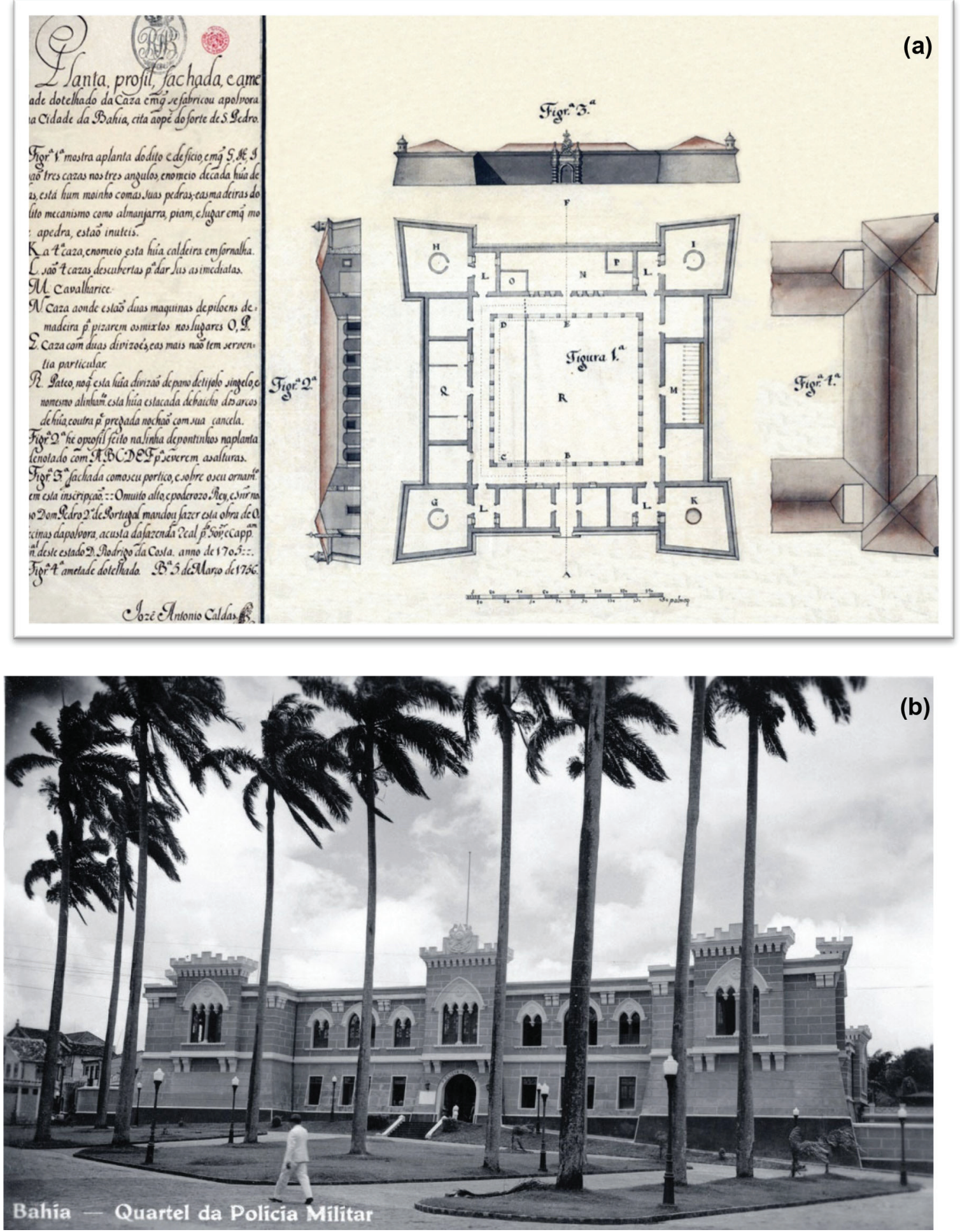

Figura 2. a) planta e perfis criados por José Antônio Caldas; b) fachada do prédio reformada em foto de 1937 (Salvador Turismo - http://www.salvador-turismo. com/aflitos/quartel.htm)

prática que, em poucas décadas, era preponderante nas prospecções minerais realizadas pelos naturalistas e mineralogistas do século XIX. Uma carta de Bernardo José de Lorena, governador de Minas, informava sobre a descoberta de nitreiras naturais na capitania para D. Rodrigo de Sousa Coutinho, além de enviar amostras diversas em 20 de fevereiro de $1800 .{ }^{17}$ No documento, Lorena cita o "Dicionario das Artes, Sciencias, impresso em Londres em 1764 por Owen" com a tradução do pequeno trecho:
The earth from which nitre is made, both in Persia and the East-Indies, is a kind of marl, found on the bare cliffs on the sides of hills exposed to the northern or eastern winds, and never in any other situation. ${ }^{18}$

Lorena traduz 'marl' como a "pedra calcária, tenra, gorda e russa", assim como uma amostra que ele estaria remetendo a D. Rodrigo junto à carta. Essa teria sido uma descoberta do Capitão Francisco Jozé da Silveira, da Companhia do $2^{\circ}$ Distrito de Cavalarias 
ROTA DO SALITRE BRASILEIRO

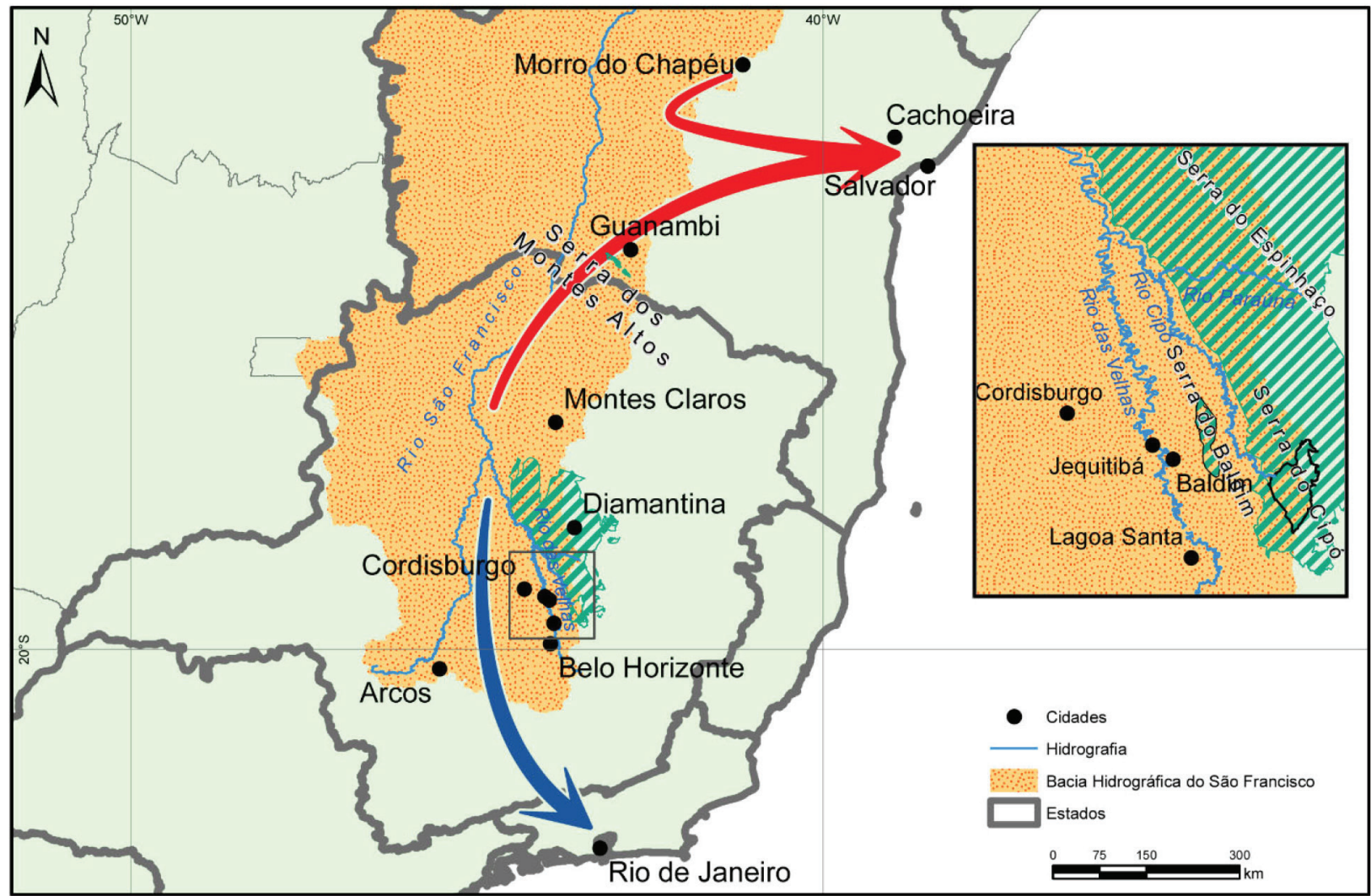

Figura 3. Localização geográfica do Parque Estadual da Serra dos Montes Altos, Bahia, próximo à divisa com o estado com Minas Gerais e as rotas que o salitre tomou para chegar até o local de beneficiamento

de Milícias da Comarca do Serro que analisou a pedra "cozinhando-a" para dela se extrair o salitre que enviara em separado com as outras amostras.

A Serra dos Montes Altos voltou a ganhar atenção no início do século XIX em um manuscrito, ${ }^{19}$ datado de 1816 e escrito por Joseph (ou José) de Sá Bitencourt Accioly, irmão do conhecido Intendente Câmara, que explorou a serra em 1799 e dela deixou um detalhado relatório. O mesmo texto também pode ser encontrado no periódico "O Auxiliador da Industria Nacional" de $1845,{ }^{20}$ com poucas modificações. No documento original, encaminhado ao Governo da Capitania da Bahia e à "Sua Majestade", o autor descreve a exploração que faz em uma série de "lapas alpendradas da chuva", ou cavidades naturais também designadas atualmente por abrigos. Nelas a presença de um filão ou veio específico (e aqui é difícil dizer com certeza do que se tratava esse veio de calcário ou de arenito - outra rocha silícica) que já havia sido alvo de extração por mineradores anteriores a ele. Além de percorrer toda a serra e dar descrição das formações geológicas da região, Accioly realiza análises químicas no salitre que extraiu em diversos locais.

E apesar dessa "Memória, sobre a viagem do terreno nitroso" ser extensamente detalhada, um dos pontos de destaque é sua proposta de como o salitre podia ter sido formado a partir de descargas elétricas atmosféricas naturais, os relâmpagos, comuns naquela região em dias de chuva:

O ar, que conforme observações de M. J LeMort se tornava necessário para a formação do nitro, como agente, ou fermentante dos seus princípios, agora que melhor se conhece a razão suficiente do modo como ele obra, seguindo as observações de M. Cavendish, na combinação de sete partes de ar puro, três de ar impuro com o choque da faísca elétrica para produzir o ácido nitroso (nome antigo do ácido nítrico). Estas verdades que tem sido tantas vezes demonstrado, não deixarão de aumentar de evidencia com que observei: logo que esta combinação se forma, e aparece o ácido nitroso, achando este a base própria para a formação do nitro pela grande afinidade que tem se une com ela de preferência a outro qualquer corpo, e da princípio ao nitro, que então começa a aparecer formando a sua eflorescência, que é tanto maior, quanto o lugar é próprio, livre não só da chuva, como da violência dos raios do sol, que sendo muito fortes faz secar a terra, e volatilizar o ácido nitroso das delicadas agulhas da eflorescência, deixando-a sobre a superfície da terra a sua base como observei a qual fazia com o ácido nitroso efervescência. ${ }^{21}$

Na versão modificada de 1845, publicada na revista $O$ Auxiliador, o texto foi alterado e no lugar de LeMort é feita a menção a " $M$. Hellot", que provavelmente deve ser Jean Hellot (1685-1766). O holandês Jacobus LeMort (1650-1718) atuou como químico e médico em Leiden, Holanda, enquanto Hellot teria se destacado por seus importantes tratados sobre corantes vegetais na França. ${ }^{22}$ É provável que ambos devam ter publicado trabalhos referentes ao salitre. Outro ilustre cientista referido por Accioly é Henry Cavendish (17311810), que foi um importante filósofo natural que utilizava descargas elétricas para promover reações químicas entre gases. Em um de seus experimentos, Cavendish conseguiu unir o "ar puro" (ou oxigênio) ao "ar impuro" ou "mofeta" (nitrogênio), que publicou no periódico Philosophical Transactions em 1788. No artigo intitulado "On the conversion of a mixture of dephlogisticated and phlogisticated air into nitrous acid, by the electric spark", ele ainda tratava o nitrogênio como "ar desflogisticado". ${ }^{23}$ 
Accioly conclui sua memória dando apontamentos sobre a climatologia do local, da administração ou governo necessário e da exportação, que seriam necessários para a exploração e envio do salitre produzido no interior da Bahia para os locais de consumo. No entanto, mesmo apesar da publicação de 1845 no Auxiliador, nenhuma outra menção a extração desse mineral nos Montes Altos voltaria a ganhar interesse. Isso pode ter ocorrido por causa da já iniciada exploração do salitre em Minas Gerais que teria sua exportação facilitada ao seguir a mesma rota do ouro e dos diamantes descobertos no interior da capitania (ver Figura 3), ao contrário do que parece ter acontecido com as primeiras descobertas de salitre no norte e centro Minas que rumavam para o nordeste em direção a Salvador.

\section{A EXPLORAÇÃO DO SALITRE NAS 'MINAS GERAES'}

Após indicar a extração de salitre em Montes Altos na Bahia, o relato de Felício dos Santos (já citado anteriormente) continua mencionando acertadamente o território das Minas Gerais como fonte do mineral. A descoberta foi feita em 1757 por dois "aventureiros", Miguel Luiz Filgueiras e Antônio José Fernandes - o primeiro, partindo do Tijuco (atual Diamantina), vai ao encontro do segundo, que residia na confluência do rio das Velhas com o São Francisco - e então juntos

embrenhárão-se ambos pelos sertões; e depois de muitas fadigas, trabalhos e perigos por que passárão, descobrirão afinal uma rica nitreira da serra da Lapa, que formava os confins do districto diamantino com a comarca do Sabará. ${ }^{24}$

A descrição não fornece mais detalhes dessa viagem, mas dá a entender que os aventureiros navegaram rio acima o Velhas e depois margearam ou o rio Paraúna ou o rio Cipó, pois ambos têm suas nascentes na dita "serra da Lapa", hoje também conhecida como Serra do Cipó. É interessante destacar aqui que o texto continua mencionando que os tais aventureiros teriam informado seu achado a Thomaz Roby de Barros (ou Tomás Rubi de Barros Barreto) que, assumindo provisoriamente na tríade Junta Governativa do Brasil, despachava orientações da cidade de Salvador.

Felício dos Santos cita ainda que no ano de 1757 a Corte dava muita importância à mineração do salitre e apresenta em seu livro uma ordem dirigida ao ainda intendente dos diamantes Thomaz Roby de Barros em 04 de Julho:

Sua Magestade remette a v. m. a copia inclusa da carta, que dirigio na presente data ao conde dos Arcos, vice-rei e capitão general d'este estado, sobre o grave negocio da extracção do salitre, produzido na serra dos Montes Altos, junto ás minas do Fanado nas visinhanças do arraial do Tijuco, de que remetteu as amostras Pedro Leonino Mares em 24 surrões, que chegárão a este reino no fim do anno passado; e ordena o mesmo Senhor que v. m. examine tudo quanto puder sobre o conteúdo n'ella, passando pessoalmente a fazer o dito exame, para o que se abonarão á v. m. todas as despezas que fizer, e de tudo dará conta com a maior individuação para ser presente á Sua Magestade, e se poder tomar a última resolução em negocio de tanta ponderação. ${ }^{25}$

Aqui, Santos observa "que existindo os Montes Altos cerca de cem legoas distante do Tijuco, não fôra muito geographico collocal-os nas suas visinhanças como reza a ordem citada". ${ }^{26}$ Isso é o que leva a crer que em toda a região do norte de Minas, onde os diamantes abundavam, também havia o interesse estratégico na produção de salitre. Pesquisadores contemporâneos ${ }^{27}$ indicam ser 'Pedro Leolino
Mariz’ (e não Pedro Leonino Mares, como descrito e destacado na citação anterior) o descobridor de uma das minas de salitre de Montes Altos "no alto Sertão da Bahia". Leolino foi o intendente das Minas do Fanado e prestava serviços à coroa portuguesa na busca por demais minérios e pedras preciosas. Sua presteza apoiou na conquista e exploração da região entre o norte e nordeste de Minas Gerais e sudoeste da Bahia entre as décadas de 1720 até $1750 .^{28}$

Essas menções feitas por Felício dos Santos são embasadas por um importante documento atribuído a Bernardo José de Lorena - o Conde de Sarzedas - que assumira o governo das Minas Gerais em 09 de agosto de 1797. Ele envia uma carta endereçada a D. Rodrigo de Sousa Coutinho, secretário de Estado dos Domínios Ultramarinos, dando notícia de achados de nitra (salitre) e enviando amostra da mesma $^{29}$ (devido à importância dessa carta e sua relação com todos os demais fatos mencionados até aqui, o completo conteúdo dessa carta se encontra publicado junto a este artigo, ver Material Suplementar). Na carta, Lorena responde um Ofício Real endereçado ao Visconde de Barbacena, seu antecessor, que ordenava o "Doutor Joaquim Velozo de Miranda" a averiguar a verdadeira situação das nitreiras naturais do rio São Francisco. A cargo desse naturalista deveriam ser avaliados a pureza do produto e condições financeiras sobre seu envio a alguma metrópole, além de calcular as despesas ao reino para a produção de pólvora. Coutinho envia ainda uma carta de apresentação de Velozo, ${ }^{30}$ datada de 10 de novembro de 1796 que indica que

O Doutor Joaquim Velozo de Miranda, que se encontra em Minas Geraes tem ordem de hir ao Rio de São Francisco examinar as nitreiras naturaes, que conta haver naqueles districtos, e remeter para esta corte algumas amostras do Salitre, que achar, com algumas observaçõens e calculos sobre a utilidade que se poderá tirar deste descobrimento.

No entanto, Velozo dizia estar com a saúde abalada e que tinha que acabar suas incumbências anteriores. Uma delas seria de realizar testes na nitreira artificial que acabara de criar, além de se encarregar da fábrica de pólvora da "Fazenda do Mau Cabello" - provavelmente localizado no arraial de Ouro Branco - e selecionar sementes e mudas de plantas para enviar ao Jardim Botânico de Ouro Preto. ${ }^{31}$

Ainda no ofício (Material Suplementar), Lorena descreve que Velozo não acreditava na existência de nitreiras naturais em abundância e julgava ser "huma raridade" a presença delas. O naturalista estava crente que o salitre que produziria em sua nitreira artificial seria suficiente para alimentar a fábrica de pólvora que ele descreve em carta a Dom Rodrigo de Souza Coutinho no ano de 1800, enviada de Vila Rica. ${ }^{32}$ A carta detalha não só as diretrizes do empreendimento, mas também todo o funcionamento da salitreira, cujas "flores salinas", obtidas por cozimento, já teriam gerado salitre e sal marinho. E apesar de não poder afirmar sobre a quantidade do produto a ser obtido em sua nitreira, Velozo indica os equipamentos e a mão de obra necessários à sua produção de salitre artificial seria mais vantajosa que a exploração de salitreiras naturais distantes de centros metropolitanos, como no norte de Minas ou sul da Bahia. Vale ressaltar mais uma vez que os nitratos apresentam razoável solubilidade em água, a perda em massa ou mesmo a descaracterização de sua qualidade nas viagens desde o beneficiamento nas salitreiras naturais até as fábricas, a "légoas" distantes, faziam depreciar a extração do produto. Os métodos de transporte na época (em lombos de mula e/ ou canoas no interior de bruacas - caixas quadradas revestidas com couro bovino), sujeitava o salitre a situações em que umidade, chuvas e rios poderiam deteriorar o produto.

Lorena termina seu ofício (ver Material Suplementar) falando que João Manso Pereira, outro célebre personagem abordado em diversos ensaios sobre história da química, ainda não havia chegado 
a Vila Rica, em Minas Gerais. No entanto, no lugar de Velozo ou João Manso, Lorena diz que poderia enviar o Doutor José Vieira Couto como encarregado para fazer ensaios mineralógicos e analisar pessoalmente as salinas do São Francisco.

Vale destacar que João Manso era um naturalista amador que obteve êxito em diversos procedimentos que incluíam desde a construção de alambiques modernos para a época até mesmo a obtenção de salitre em nitreiras artificiais que tentou criar na cidade de Santos - SP, utilizando para isso a urina dos moradores. ${ }^{33}$

Junto à carta de Lorena (ver Material Suplementar) existem ainda cópias de documentos que esse governante enviou ao Rio de Janeiro e que relatavam a presença de salitre numa ou noutra capitania. O primeiro documento reafirmava a descoberta do composto em Montes Altos, por Bernardo Barboza e Castro, o qual manifestava sua descoberta ao Mestre de Campo e Regente de Minas Novas, Pedro Leolino Mariz. O segundo documento confirma a diligência realizada por Manoel Cardozo Saldanha - o mesmo tenente coronel indicado nos mapas como responsável pela conquista daquelas partes do sertão. No entanto, o desentendimento da equipe que partiu com ele de Salvador fizera que seu empenho em produzir salitre fosse frustrado. Todo o aparato que Saldanha carregava foi deixado em um rancho onde boa parte do material (tachos de cobre, caldeiras, rolos de estanho etc. - ver Material Suplementar) foi perdido com o tempo. Outra confirmação dada por Saldanha é a localização do Morro do Conde, onde Marcos José de Noronha e Brito (1712-1768), o Conde dos Arcos, repousou de sua viagem da capitania de Goiás até a Cidade da Bahia.

$\mathrm{Na}$ segunda memória anexada à carta de Lorena (ver Material Suplementar), mais geral e resumida, descreve-se também a descoberta de salitre no coração da capitania da Bahia (para ser mais exato, na atual cidade de Morro do Chapéu). A descoberta foi atribuída ao Capitão Miguel Luiz Filgueiras que minerava diamantes dentro das Demarcações Diamantinas em Minas Gerais. Ele foi o responsável por averiguar as insinuações da existência de salitre nas serras do rio Pardo Pequeno, nas proximidades do Tijuco, o que também se enquadra na descrição de Felício dos Santos.

Contudo, apesar das referências de Felício dos Santos e da carta de Lorena, um dos documentos mais antigos que relatam a existência de salitre em Minas Gerais foi feito pelo governador e capitão general da capitania de São Paulo, o quarto Morgado de Mateus, Dom Luís Antônio de Sousa Botelho Mourão. Essa correspondência é encaminhada ao secretário de estado da Marinha e Ultramar, Francisco Xavier de Mendonça Furtado (irmão do Marquês de Pombal), em 1769, em resposta à carta que ele encaminhara ao governador, em junho de 1766 que recomendava que

fizesse examinar onde estavão os materiaes, que me informarão havia por certas partes para fabricar a pólvora, especialmente o salitre". Seu ofício continua ao citar que "Em Minas na Serra* (sic) me afirmarão que havia, lá mandey, mas porque era Capitania alheia, não pude fazer o devido exame que eu queria. ${ }^{34}$

$\mathrm{O}$ asterisco em destaque após a palavra 'serra' é indicado por D. Luís Antônio como sendo a "Serra da Lapa”, já citada anteriormente nos achados de Miguel Luiz Filgueiras. O governador termina sua comunicação indicando que na vila de Guaratinguetá havia o tão precioso mineral, de acordo com informação recebida em 1768 por Luís de Vasconcelos e Meneses. ${ }^{35}$

Nesse ponto, faz-se necessário mais uma vez o retorno ao relato do historiador Joaquim Felício dos Santos ${ }^{36}$ para a correta sequência cronológica dos fatos referentes ao salitre em Minas Gerais. No capítulo XXIX ele afirma que
Ricas nitreiras abundavão disseminadas pelas terras do districto diamantino, e principalmente ao noroeste, nos sertões ao longo da serra do Cabral e nas cavernas da mesma serra; sendo, porém, prohibido o fabrico da polvora, e não alcançando o salitre senão um preço baixo em razão das grandes despezas e difficuldades de sua exportação aos lugares de seu consumo, achava-se esta rica indústria quasi abandonada. Explorava-se uma ou outra lapa de trabalho mais facil, ou antes a unica indústria consistia em apanhar o salitre puro e cristalizado, que se firmava na superfície das nitreiras, só para o uso da pharmacia, ou para o fabrico clandestino da polvora em quantidade insignificante.

Felício dos Santos indica que tais nitreiras tinham sido descobertas em 1799, no entanto não deve estar se referindo ao local correto. A referida "Serra do Cabral", com o mesmo nome que é conhecida atualmente, dista $40 \mathrm{~km}$ da barra do Rio Paraúna com o Velhas e $60 \mathrm{~km}$ da barra do Rio Cipó com rio Paraúna. Essas regiões foram indicadas em mapas históricos, situando rios que banhavam ricas paisagens de serras e matas, e apontam também diversas nitreiras/nitrateiras/salitreiras naturais em um ou outro lado dos referidos rios (Figuras 4 e 5). A cartografia de meados do século XVIII preocupou-se muito com a precisão da localização do salitre na capitania de Minas Gerais, o que pode indicar a necessidade do conhecimento do custo do transporte do produto mineral até os portos do mar ou mesmo da presença de rios que pudessem alimentar uma fábrica de salitre.

Apesar do mapa (Figura 4) não trazer data exata (é indicado como sendo criado a partir de 1758), ${ }^{37}$ ele descreve as descobertas feitas por Miguel Luiz Filgueiras e por Antônio J. Fernandes em um "Roteiro cosmográfico" elaborado a mando de Thomas Roby de Barros Barreto. Na extensa nota explicativa do mapa (emoldurada em um escudo à direita da imagem) ainda constam a descrição de cada uma das pedreiras, lapas ou cavernas, sítios e roças. A nota indica também a existência de salitre e a possibilidade de se criarem açudes e engenhos. O mapa também dá a indicação de pontos em que água poderia ser captada para alimentar as fábricas de salitre que poderiam ser estabelecidas no local.

Outro interessante documento cartográfico (Figura 5), também sem data exata (ca. 1803), ${ }^{38,39}$ mostra uma homenagem feita por José Vieira Couto a Rodrigo de Souza Coutinho que ocupava em 1801 o cargo de Secretário de Estado dos Negócios Estrangeiros e da Guerra. Couto batizou essa porção geográfica com o nome Monte Rorigo, atribuindo a homenagem ao secretário a um monte nas proximidades de Senhora da Glória, distrito hoje pertencente ao município de Santo Hipólito (Figura 5). Sobre esse monte, Couto deixou uma extensa Memória e indica que a mesma "he huma Cordilheira de formosos montes, e huma daquellas, que por ventura o tempo nunca a aplainará". ${ }^{40} \mathrm{Em}$ todas as quatro memórias que apresentou ao governante da Capitania de Minas Gerais, Couto, com maestria, mesclava uma descrição narrativa científica atrelada às vertentes geológicas então correntes na Europa com uma redação poética profunda, reflexiva e nacionalista, conforme nos esclarece a obra de Clarete Paranhos da Silva ${ }^{41}$ ao apresentar Vieira Couto e suas obras. Vieira Couto calculou os custos do envio do salitre até os portos costeiros que avaliou " $5 \$ 000$ a $6 \$ 000$ reis" (cinco a seis mil réis) por arroba de salitre.

Abre-se um parêntese neste parágrafo para pontuar que é inédita a indicação dos mapas e documentos cartográficos que até o presente momento não haviam sido feitas em nenhum outro trabalho de análise histórica. Esse difícil labor tem por empecilho a errônea imputação de nomes de rios e de localidades que sofreram modificações e não permitiam a correta indicação atual em mapas. 


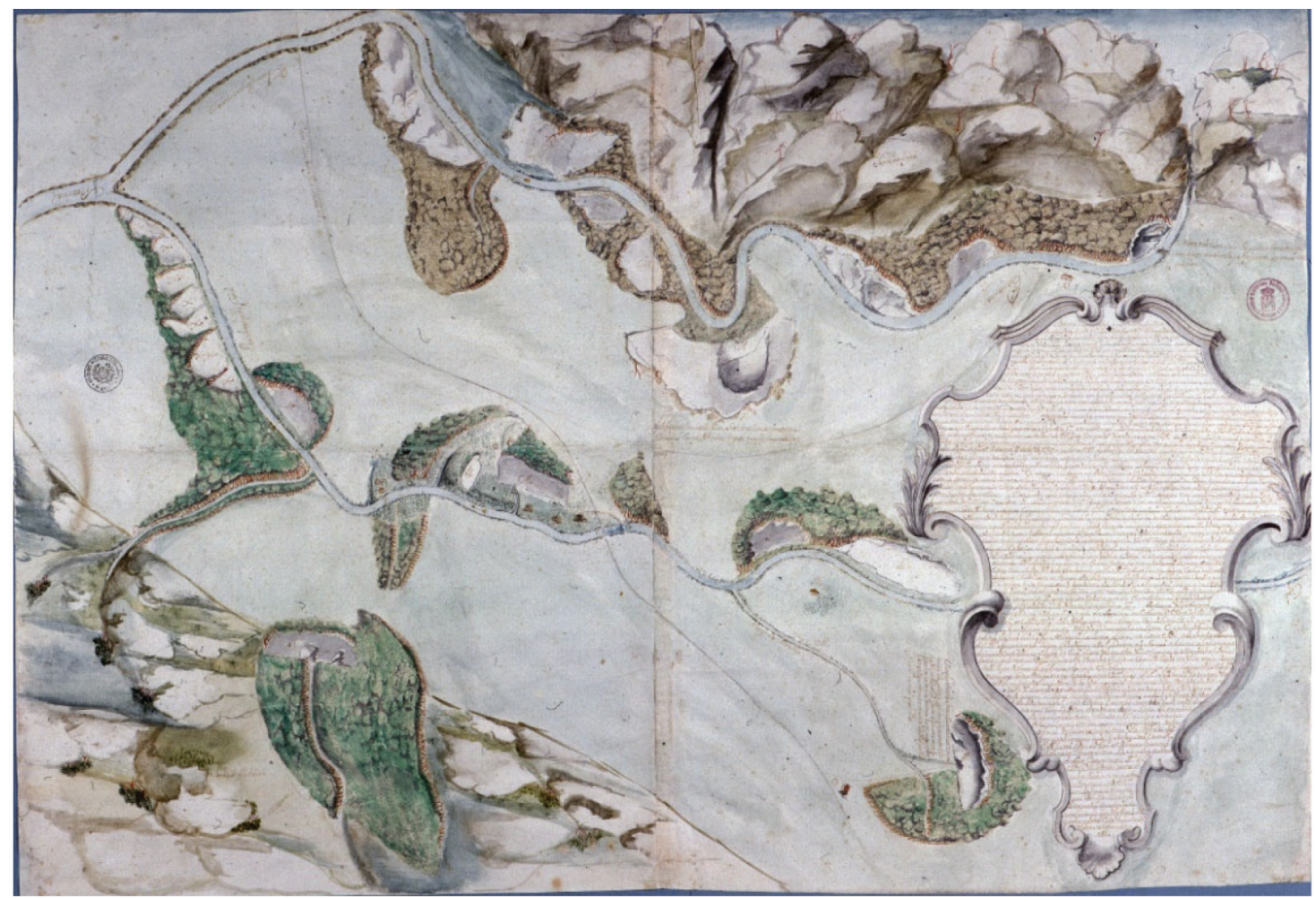

Figura 4. Mapa cartográfico histórico das confluências do rio Cipó e do Paraúna com indicações de salitreiras nas proximidades da serra da Lapa ${ }^{37}$

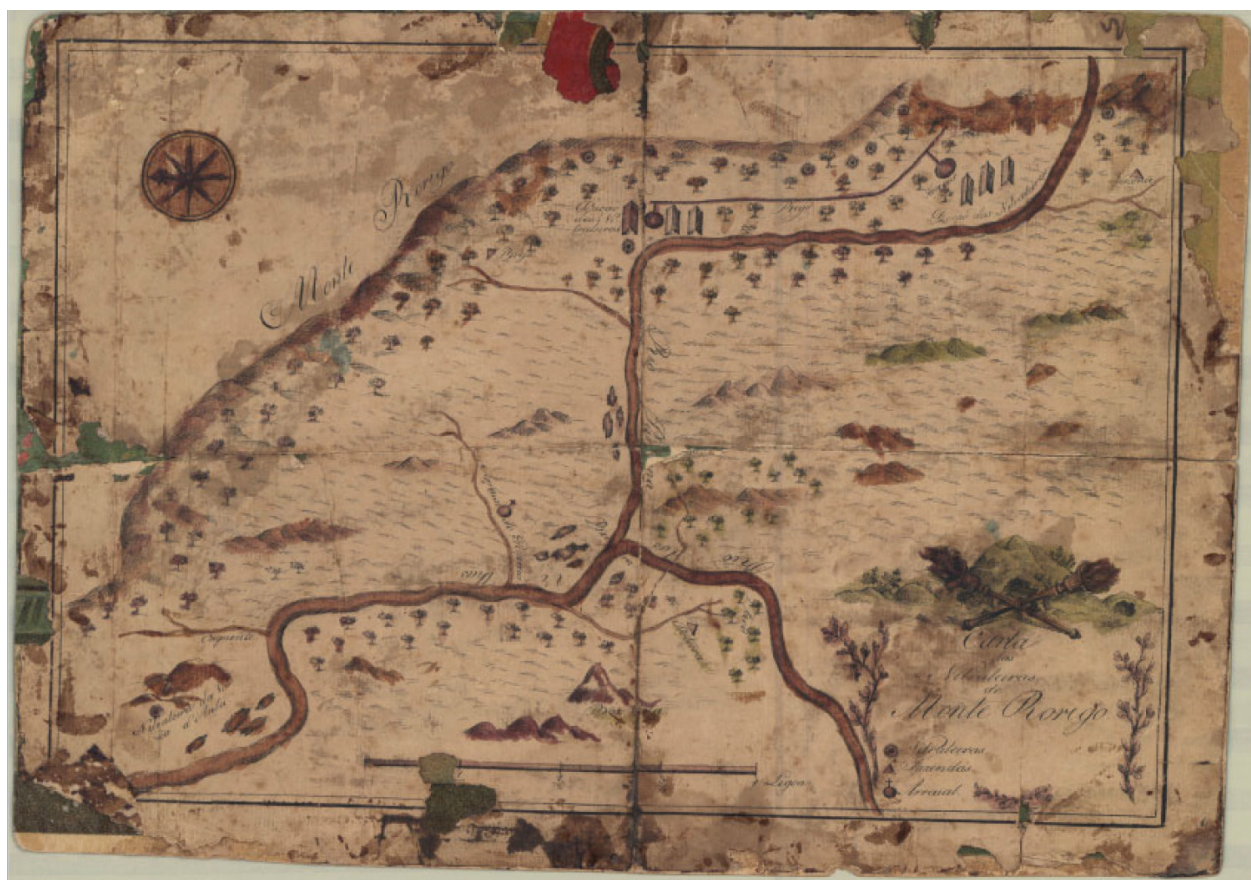

Figura 5. Mapa das confluências do rio Paraúna e do rio das Velhas com indicação de salitreiras nas proximidades do Monte Rorigo ${ }^{40}$

Isso ainda sem contar que a Figura 5 é indicada como pertencente a documentos referentes à capitania da Bahia no Arquivo Histórico Ultramarino - AHU. Espera-se que essa contribuição permita um melhor conhecimento dos documentos e das áreas indicadas nos mapas e que, além de servir como ferramenta para a tomada de medidas públicas, promova a conservação das ditas nitrateiras ou cavernas, e proponha ainda o ecoturismo sustentável nos entornos de tão belas paisagens mineiras.

É interessante notar que, apesar de não cunhar o nome Serra do Espinhaço, Vieira Couto indica no início de sua memória - após uma digressão de elogios ao Rei e ao Ministro - que "de Norte a Sul por huma longa, e sinuosa Serra, que como seu espinhaço, o divide quase em duas partes iguaes, e cuja Serra "em outras de minhas Memorias a appellidava a Grande Serra de Minas". ${ }^{42}$ Hoje tal conjunto de serras que, tal qual a espinha central divide os animais em lados esquerdo e direito, a Serra do Espinhaço divide Minas Gerais em duas porções (hoje é atribuído a Eschwege o batismo dessas elevações da porção central do Brasil). Sem apenas apelidar as formas geológicas do estado, Couto ainda dá indicações sobre as formações pedológicas (referente a solos) e de 
rochas, sobre vegetação, clima e moradias. Ele descreve o salitre, em diversas ocasiões, como "nitrato de potassa" associando sua presença a locais de formações carbonáticas (calcário), atmosfera quente e úmida. Além dessas condições Couto alega que "outras circunstancias mais, por ventura próprias do local, parecem concorrer para a producção desta preciosa droga". Tendo partido de Diamantina, ele narra na Memória sua viagem em direção ao monte Rorigo, na rota em direção ao poente. Do alto da serra começa a ver o "negrejar" das sobreditas rochas calcárias, de coloração normalmente acinzentada. Na página 12, Vieira Couto responde a uma das dúvidas levantadas no começo desse texto quando fala da presença do dito sal na serra que descreve do poente:

As mais vastas cavernas porém, e as mais ricas são as que jazem no sobpé da Serra, e pela maior parte aproximadas a grande rios, ou ribeiros. Os esbarrancados, que operarão estes mesmos rios, cavando seus leitos, tantos séculos há, e solapando as grandes rochas calcareas, que sustentão, $e$ formão suas ribanceiras, a humidade, que descendo da Serra, e dos montes visinhos, reçuma (ou ressuma: líquido que se infiltra e lixivia) por baixo destas rochas, e as vai descalçando das terras, que as entremeião; são as principais causas, $e$ origem destas grandes lapas, ou Salitreiras Naturais. ${ }^{43}$

Usando, como ainda se empregam, os sinônimos das palavras 'caverna' e 'lapa', Couto indica serem as grutas encontradas nas proximidades do Distrito Diamantino aquelas que contém o material derivado da intensa ação das águas sobre as rochas calcárias. Dela então se extrairia o salitre, conferindo o termo 'salitreiras naturais' às cavernas, local propício para fixação e concentração de nitratos.

Couto, ao continuar de sua narrativa, descreve melhor os "soterrâneos" ao afirmar que as cavernas existentes que observara a leste da Grande Serra - muito provavelmente cavernas desenvolvidas em litologia quartzítica - apresentavam "tectos, e pavimentos tudo he construido da rocha dominante areenta do lugar". O quartzito, como supõe o nome, é uma rocha criada da deposição de grãos de areia de composição predominantemente siliciosa $\left(\mathrm{SiO}_{2}\right)$ ou, como descreve o naturalista: "vitrescível, inatacavel pelo Acido Nitrico, hum dos principios do Nitrato de Potassa". ${ }^{44}$ Aqui Vieira Couto está demonstrando seu conhecimento químico ao indicar que o material silicioso não reage ao $\mathrm{HNO}_{3}$, enquanto o contato desse ácido com rochas carbonáticas como o calcário $\left(\mathrm{CaCO}_{3}\right)$ produz gás carbônico, água e o nitrato de cálcio em uma reação efervescente. Vieira Couto irá demonstrar ainda mais relação ao desenvolvimento científico europeu na Memória sobre o Monte Rodrigo ao descrever o processo de "salitrificação":

O Nitrato de potassa, este sal, cuja producção, e colheita he o objecto das suas lidas, he composto de tres princípios, oxygenio, azoto, e potassa: a combinação dos dous primeiros constitue o Acido Nitrico, e este ao depois com a potassa o dito Nitrato ou Salitre... O oxygenio e o azoto formão este nosso ar atmosferico, que respiramos, porém no estado de simples mistura, e não combinação; por quanto o azoto já reduzido a perfeito gaz, e tal qual existe na atmosfera, isto he, depois de já ser dissolvido no calorico, ele repugna a esta combinação; quando pelo contrario o oxygenio parece se presta a ella com toda a facilidade. ${ }^{45}$

Nesse texto Vieira Couto assume a vertente que admitia a existência e relevância do oxigênio nas transformações da matéria, conforme o proposto pelo ilustre químico francês Antoine Lavoisier. Couto também faz uso do calórico em suas teorias para justificar as combinações que ocorriam em certos materiais na formação de compostos químicos como o salitre. Ele atribuiu ao nitrogênio o título de substância pura e simples, misturada na atmosfera ao gás oxigênio. Já esse último gás deveria ser um composto, formado pelo elemento químico oxigênio e o calórico, responsável por eventos que envolveriam o calor e a luz em processos de combustão, seguindo de perto a química lavoisiana.

Julgamento químico semelhante e contemporâneo ao descrito por Couto é dado por um imenso texto das Memórias Econômicas da Academia Real das Sciencias de Lisboa ${ }^{46}$ de 1812. A matéria traz um trabalho feito pelo médico da Família Real Portuguesa, José Martins da Cunha Pessoa (1745-1822), que expõe a "opinião mais geralmente recebida" à época na sua "Memória sobre o nitro, e utilidades, que delle se podem tirar":

que as substancias animaes quando apodrecem, dão o Gaz Azotico; e que os vegetaes favorecem muito a produssão da Potassa: Aquele gaz encontrando o Oxygenio no ar atmosferico vem a formar o Acido Nitrico, depois de perder a porção de calorico, que o continua no estado aeriforme, e por isso mesmo mais facil de se combinar com o mesmo Oxygenio nas doses precisas para constituir o Acido Nitrico. Resta averiguar pois como a Potassa, para formar o Nitro com este acido se pode produzir: a opinião mais provavel, e que alguns Chimicos dão por quase demonstrado he, que na composição da Potassa entra a terra calcarea, e o Azote combinados pela força da vegetação das plantas, ou para melhor dizer, ajuntados pela força dos vegetaes, que entrão nas Nitreiras naturaes.

É interessante notar que, em princípio, pode-se verificar pelo texto de Cunha Pessoa, a crença nas teorias de Lavoisier e ainda a questão da fixação do "Gaz Azotico" ou nitrogênio gasoso pelas "plantas". Tais teorias não admitem a ação de microrganismos fixadores de nitrogênio que até a época eram completamente desconhecidos. Mesmo após décadas, a formação do salitre em cavernas foi muito atribuída à decomposição dos amontoados de fezes de morcegos (também denominado de guano), apontados como a verdadeira fonte dos nitratos em ambientes cavernícolas. No entanto, $\mathrm{Hill}^{47}$ demonstrou que apesar de enriquecer os sedimentos internos de cavernas com nitratos, o guano não é nem a única fonte e nem a mais importante contribuição na formação do salitre em ambientes subterrâneos. A autora afirma que a presença de bactérias nitrificantes nas rochas e no solo oxidam o nitrogênio orgânico ao nitrato $\left(\mathrm{NO}_{3}{ }^{-}\right)$e esse, dissolvido em águas naturais, percolam e enriquecem os sedimentos.

Vieira Couto continua dando informações acerca da química envolvida na formação dos depósitos de salitre nas cavernas, afirmando que são as rochas calcárias as responsáveis por prender o nitrato de potassa, pois ele formava com elas um "nitrato calcário" [aqui deve referir-se ao $\mathrm{Ca}\left(\mathrm{NO}_{3}\right)_{2}$ ]. Mesmo nas mais vastas lapas das formações quartzíticas, a presença do salitre - continua Couto - só era possível em algumas frinchas e corredores estreitos "por onde parece que correo, е reçumou (atravessou por poros ou marejou) alguma potassa, despojo das árvores, e arbustos, que assombrão por fóra estes arredores". ${ }^{48}$ Aqui o doutor está em acordo com as propostas atuais para a formação do salitre nas grutas através da ação da decomposição do material orgânico rico tanto em compostos orgânicos nitrogenados e pelo potássio. Esse cátion $\left(\mathrm{K}^{+}\right)$está presente nas plantas e pode ser obtido na forma de carbonato após a incineração de madeira em recipientes adequados. 
Ao descrever o relevo que encontra, Couto se mostra deslumbrado pela aparência e aponta o que hoje se indica no estudo do carste (terreno formado pela corrosão de rochas solúveis como o calcário, caracterizado por leitos subterrâneos ou cavernas) como uma de suas características:

Infundem suas vistas prazer, e admiração a quem de longe, descendo a Serra, as observa; notando suas bocas abertas, humas sobrepujando outras, ou correndo em fio ao longo do rio, branqueadas pelas estalactites, entremeadas de escuras matas, e representando velhos edifícios de Architectura Gotica, cahidos já em ruinas. ${ }^{49}$

Essa característica 'ruiniforme' é predicado máximo de relevos como os de Lagoa Santa, Sete Lagoas, Pains e Doresópolis, onde se encontra a importante Formação Geológica Bambuí e predominam os carbonatos. Uma das cavernas que ele descreve e onde a tropa se abriga para passar a noite é denominada "Estreito de Pedra". Infelizmente os nomes de Monte Rorigo, dos distritos descritos ou da caverna citada não permanecem os mesmos até hoje. O local exato não se pôde precisar pela análise do texto, mas o caminho percorrido pelo naturalista indica que ele estava a 14 léguas (cerca de $90 \mathrm{~km}$ ) a oeste do Tijuco, atual Diamantina, concordando com a região que hoje abriga os municípios de Monjolos (47 cavernas cadastradas), Presidente Juscelino (28 cavernas cadastradas), Santo Hipólito (7 cavernas), Augusto de Lima (7) e Corinto (6). De um total de 95 cavidades conhecidas atualmente ${ }^{50}$ é muito provável que algumas delas tenham sido visitadas pela tropa.

Ainda de tom poético e de agradável leitura, José Vieira Couto narra agora a visão que tem do teto da citada Caverna do Estreito de Pedra:

Enleava-me o seu largo, e espaçoso vão; no tecto alvas estalactites pendentes, humas representavão fluctuantes roupas, e de enormes grandezas, outras monstruosos cachos de uvas, aqui se vião melões, ali variadas flores: nos lados em partes se relevão, e brotão docéis globos, colchões rolados, delicadas rendas; em parte afundão grandes recameras, nichos, tudo curiosidades da Natureza, obras suas fabricadas ao seu vagar na confusão dos Seculos, $e$ pingo a pingo! Estas cavernas, dignos templos da magestade de hum Deos Pythio, ou de uma Sybilla de Cumas, onde homens cheios de pavoroso respeito, tremendo irão ouvir da boca de outros homens, e em nome da Divindade, a futura historia de seus destinos; estas cavernas, onde até hoje tem reinado huma profunda paz, e solidão, hum dia serão desfiguradas para dellas se extrahir o branco sal, que nos dias de terror, e no campo da morte, entre nuvens de fumo, e linguas de fogo, irá aumentar a confusão, o horror, a destruição. ${ }^{51}$

A descrição fantasiosa dos Espeleotemas (conjunto de formações espeleológicas secundárias criadas a partir da deposição de calcita em formações como as estalactites e estalagmites) no interior da gruta fascina Couto pelos vultos imaginativos criados por ele. Isso também lhe causa indignação por saber da necessidade da destruição de tais vultos devido a utilização dos espeleotemas para extração da matéria prima da pólvora nas guerras campais. É possível crer que estalactites e estalagmites tenham sido "cozidas" nas fábricas de salitre e dessa forma perdidas para a extração do sal. Após falar de prováveis fósseis "de vermes" (provavelmente de conchas de caramujos do gênero Megalobulimus comuns em cavernas), de pisos com camadas calcíticas e de espeleotemas quebrados e caídos, Couto afirma que nem todas as cavernas visitadas eram grandes como a caverna Estreito de Pedra.

Porém todas as cavernas "Abundam (...) em vários saes, sendo porem os dominantes, e em maior quantidade os Nitratos de potassa, de cal, e de Magnésia. Seguem-se depois os Muriatos de soda, terrosos, e alguns Sulfatos muito menos ainda que os Muriatos". Nesse último ponto o autor mostra uma discordância com o seu texto manuscrito, ao qual teve acesso Felício dos Santos e que descreve a mesma frase apontando que "O mais são os muriatos de sóda, cal, amoniaco, como tambem sulfato de magnésia". De uma forma ou de outra, o naturalista, além de indicar o conhecimento de diversas substâncias inorgânicas, deve ter sem dúvida capacidade química de ensaiar alguns dos compostos em campo ou no laboratório que mantinha no Tijuco. Essa herança científica aplicada na busca de bens minerais está de acordo com o que foi analisado sobre aquelas instruções do prodigioso professor de Couto, o italiano Domingos Vandelli. Silva ${ }^{52}$ resume, informando que:

As fontes minerais deveriam ser examinadas com o maior cuidado. O naturalista deveria levar consigo vidros e ácidos necessários para as análises, ou levar amostras de águas em frascos para serem analisadas em melhores condições.

Vandelli adotava a ideia de que a ciência não teria significado se não fosse o de prover avanços sociais, aplicados à descoberta de materiais úteis. Esse professor havia participado da fundação da Academia Real das Ciências de Lisboa, cujo lema até hoje é "Nisi utile est quod facimus stulta est gloria" - "se o que fazemos não é útil, tola é a glória”. Isso fica claro no trecho:

O que fica dito do reino das pedras abraça em geral todas as coisas que se deve propor o naturalista para fazer uma história completa dos lugares por onde passar, e um sortimento das produções mais úteis da natureza que possam servir de interesse à sua Pátria, único fim a que devem tender as fadigas de um filósofo que viaja. ${ }^{53}$

O fato é que, como tutor de Vieira Couto, Vandelli foi um dos responsáveis por Couto utilizar seus conhecimentos científicos no levantamento das potencialidades econômicas de Minas Gerais.

A hipótese dos ensaios em laboratório que foram realizados por Vieira Couto pode ser confirmada por correspondência datada de 1799 e manifestada por Couto a D. Rodrigo Souza Coutinho. ${ }^{54} \mathrm{Na}$ carta ele expressa descontentamento tanto pela perseguição que sofre pelos responsáveis da Demarcação Diamantina, quanto pela falta de utensílios em seu laboratório, o que impediu as importantes análises que fazia sobre os recursos minerais da capitania. Couto narra que

Seis meses ha q vi-me na posição de escrever a V. Exa. dando pe. dos incomodos q tenho sofrido, tanto na falta dos meios de subsistencia, q o presente governo de Tijuco me tem procurado, (...). Tenho tãobem experimentado Exmo Senhor, grande dificuldade em mtas experiencias chimicas por causa de não ter o meu laboratório munido de vasos de vidro, nem nestes sertões ha por onde recorrer. ${ }^{55}$

Sem entrar nos méritos da extração e purificação do salitre, vale ressaltar que antes mesmo dos meados do século XIX a extração desse composto inorgânico já era largamente conhecida pelos governantes da capitania de Minas Gerais e pelos colonos. De acordo com o próprio Vieira Couto, a falta que a Europa sentiu por esse gênero fez que "por toda a Capitania se levantassem centenas de fabricaszinhas da mesma: o povo corria a estas Salitreiras para 
extrahir o Salitre". ${ }^{56}$ John Mawe (1764-1829) concorda com essa afirmação e deve ter conhecido o trabalho de Vieira Couto pois assim se referiu ao "Monte Rorigo":

Esta montanha é muito grande e bem arborizada; o estrato é calcário e contém muitas cavernas revestidas, por assim dizer, de nitrato de potassa. Desde que o Governo fez do nitro um objeto de comércio, e encorajou sua produção, muitas famílias se estabeleceram neste local, e tem coletado grandes quantidades desta substância salina, que, após várias operações, é mandada ao Rio de Janeiro, onde é refinada por uma grande manufatura de pólvora recentemente estabelecida próxima a cidade. ${ }^{57}$

Mawe está se referindo à Real Fábrica de Pólvora, estabelecida próxima a Lagoa Rodrigo de Freitas em 1808, hoje Jardim Botânico, cujas ruínas ainda podem ser vistas, pois fazem parte das atrações históricas do espaço. Sobrevivem parte de seu pórtico e a Casa dos Pilões, na qual eram misturados os componentes da pólvora.

O empenho comercial citado por Mawe pela extração do salitre por parte de terceiros, interessados nos lucros com a Coroa, deve com certeza ter gerado conflito com os proprietários das terras salitrosas que tinham suas terras invadidas por mineradores. Esse fato é apresentado por João Dias Rosa, escrivão da Ouvidoria Geral e Correição da Comarca do Rio das Mortes, em uma certidão referente à publicação da ordem régia de 12 de setembro de 1808 que incentivava a exploração do salitre na Capitania de Minas Gerais. ${ }^{58}$ A certidão sugere que a extração do salitre já alcançava outras comarcas de Minas Gerais, a grandes distâncias (a mais de 200 km) de onde Vieira Couto havia pesquisado.

Um interessante registro cartográfico daquela época de $1810,{ }^{59}$ que não pôde ser reconhecido em mapas atuais, mostra salitreiras naturais próximas ao Rio São Francisco nas divisas dos distritos de "Bambuhy e Formiga", ambos da Comarca do Rio das Mortes, atualmente com os mesmos nomes, em região também reconhecidamente cárstica.

Os envios de salitre e de pólvora para a Europa na intenção da manutenção da segurança em Portugal passariam a ser massivas. Um exemplo disso é o que narra o jornal "Idade d'Ouro do Brazil" na sua edição de 17 de janeiro de 1812 :

"S. A. R. o Príncipe Regente Nosso Senhor, querendo acudir com todos os meios, que lhe são possiveis para a defensa deste seu reino de Portugal, mandou nos navios ultimamente chegados do Rio de Janeiro muitas arrobas de Salitre, para consumo da pólvora". ${ }^{60}$

A descrição continua com um total de 1.934 arrobas $(28,4$ toneladas) carregados em três navios. A "Gazeta do Rio de Janeiro", em 7 de agosto de 1813, divulga um memorial a respeito das Guerras Peninsulares, informando que entre maio e agosto daquele ano o exército aliado formado por portugueses, espanhóis e britânicos expulsou o exército francês da Península Ibérica. No mesmo jornal, um edital noticia a compra de salitre das terras mineiras através do Edital: $^{61}$

A Real junta da Fazenda dos Arcenaes do Exército, Fábricas e Fundições, faz saber ao Público que, para o fornecimento da Real Fábrica de Pólvora, e seus armazéns, se propõe a comprar por tempo de hum anno toda e qualquer porção de Salitre de Minas, que se oferecer à venda pelo preço de cinco mil réis a arroba. E para que chegue à notícia de todos se mandou fixar o presente. Rio de Janeiro, 30 de Julho de 1813.
Outro ilustre pesquisador, o Barão de Eschwege (1777-1855) descreve em suas memórias, documentos e livros, algumas passagens que dão conta da produção do salitre na comarca do Rio das Mortes, hoje compreendido pelas proximidades de São João del Rei. O barão relata o encontro com os proprietários de uma pequena fábrica de salitre em uma de suas viagens pelo interior da capitania, no atual município de Arcos, que é banhado pelo São Francisco. Nessa região afloram os calcários e abundam as grutas e cavernas (quase duas mil cavidades são conhecidas e cadastradas). Eschwege, que também era conhecedor dos trabalhos de Couto (como menciona em suas notas), concorda que a extração de nitratos nas capitanias do Brasil, apesar de "especialmente rica dessas ocorrências", em nada contribuiu para o comércio externo do Império Português em virtude dos elevados preços do transporte pelo interior da colônia. Mais detalhista, porém menos poético que Couto, Eschwege descreve ${ }^{62}$ principalmente os fatos em relação a valores e custos da produção do sal. Dá detalhes sobre como ocorre a extração do salitre em algumas cavernas que hoje se acredita estarem no município de Arcos. A principal é a caverna Loca Grande (de acordo com observação do tradutor Domício M. Figueiredo, apontado nas notas que fecham a edição traduzida da obra Pluto Brasiliensis, de Eschwege), que hoje é conhecida por gruta da Cazanga (Lat. 20,285066 S; Long. 45,596328 W).

Alguns dos mais importantes naturalistas que passaram por essa capitania citam, em seus relatos de viagem por Minas Gerais, a existência de cavernas e de seu produto; esses são personagens como Auguste de Saint-Hilaire (1779-1853, francês), Johan Emmanuel Pohl (1782-1834, austríaco), Hermann Burmeister (1807-1892, alemão), Emmanuel Liais (1826-1900, francês) e Richard Burton (1821-1890, inglês). Além de indicar as localizações das cavernas, muitos deles ainda apontam em suas memórias a forma de se extrair o salitre. No entanto, cabe antes ressaltar o trabalho indireto sobre a mineração de salitre que foi desenvolvido por um dinamarquês, Peter Wilhelm Lund (1801-1880), que veio ao Brasil inicialmente para realizar trabalhos em novas descobertas botânicas. No entanto, ao conhecer o patrimônio espeleológico do interior de Minas Gerais, Lund preferiu expor às comunidades científicas da Europa suas descrições de inúmeros vestígios fósseis da denominada 'megafauna pleistocênica' extinta, que eram e ainda são descobertos nos sedimentos das cavernas, encerrados junto às terras nitrosas.

Lund dedicou grande parte de sua vida ao estudo desses fósseis. Nomeou muitas espécies que hoje são representadas em museus pelo Brasil e Europa. Contudo, antes de buscar nos recônditos subterrâneos os restos de vida e conquistar o título de 'Pai da Paleontologia Brasileira', Lund teve os seus primeiros contatos com cavernas no ano de 1834 em Curvelo, onde encontrou um conterrâneo dinamarquês. ${ }^{63}$ O ‘simples acaso' de dois dinamarqueses nos sertões do Brasil oitocentista - fato difícil de se repetir mesmo nos dias atuais! - abriria um leque de oportunidades ao naturalista que buscou a partir dali outras cavernas onde ocorreu a exploração de salitre. Antes de Lund, outros viajantes já haviam descrito a existência de fósseis contidos nos sedimentos dos interiores das cavernas e ainda de fragmentos de ossos, separados do material salitroso durante o beneficiamento do salitre. Como as condições climatológicas não favoreciam o trabalho científico em campo, no inverno do ano seguinte, Lund iniciaria um percurso que saía da cidade de Curvelo em direção à Lagoa Santa. Ao longo de todo seu caminho, descreveu cavernas que foram utilizadas para extração de salitre ou mesmo cavernas intocadas como a Gruta de Maquiné (hoje aberta ao turismo de massa), a gruta de Cerca Grande (atualmente tombada como Parque Estadual) ou a Lapa Vermelha nos arredores de Lagoa Santa (que foi destruída na década de 1980 pela mineração de calcário, matéria-prima para o cimento).

Como nos conta sua biógrafa Birgitte Holten, ${ }^{64,65}$ Lund visitou e descreveu nesse primeiro momento - junto a seu desenhista e 
braço direito Andreas Brandt - um total de 19 grutas sobre as quais deixou textos e anotações e, na maioria das vezes, também mapas detalhados das mesmas. Após ter ido de Curvelo até o Rio das Velhas, rumou até os paredões calcários do Rio Paraúna (o mesmo local indicado anteriormente por Vieira Couto como o Monte Rorigo). Lund explorou a "Serra da Baldina" ou Serra de Baldim, e descreveu as cavidades que teriam produzido milhares de arrobas de salitre. De acordo com ele apenas em uma delas, a Lapa da Paroba (ou Peroba) que foi visitada em 06 de outubro de 1835 , a gruta havia sido

muito trabalhada e, de acordo com o proprietário, deu mais que 1000 arrobas de salitre. Uma caixa dava 6-8 arrobas no início, agora somente 2. São os primeiros palmos superiores da terra que dão mais, para baixo diminui a riqueza. ${ }^{66}$

É provável que o valor total de 1.000 arrobas de salitre, aproximadamente 15 toneladas, produzido nessa única cavidade tenha sido avaliado de forma exagerada pelo seu proprietário. No entanto vale destacar que aquelas cavernas já eram trabalhadas para extração salitreira há décadas, como descreve novamente Lund, em suas notas de campo, para outra importante caverna da mesma serra:

A gruta perto de Forquilha tem sua entrada na direção NE e constitui-se de um corredor que depois se divide em vários braços ramificados, alguns dos quais sem dúvida se encontram com uma abertura que um monte de terra de enxurrada com crescimento de árvores entope (...). A altura dos corredores é de cerca de 3-12 pés e alguns estão bastante entupidos com terra vermelho-tijolo ou amareloacinzentada, contendo uma grande quantidade de fragmentos de pedra. Uma excepcional quantidade dessa terra já foi retirada, e grandes montes da mesma, lavados, espalham-se uniformemente no exterior da gruta, que vem sendo explorada há 40-50 anos. Fora dela havia dois troncos colossais. Nenhum fóssil e nem ossos. ${ }^{67}$

Essa caverna, a Lapa da Forquilha, foi visitada por Lund em 11 de outubro de 1835 e hoje se apresenta de acordo com a descrição do naturalista, salvo modificações que podem ter ocorrido mesmo após a visita do dinamarquês. Isso é notado nos corredores e salões da gruta, cujo teto pode alcançar entre 8 a $12 \mathrm{~m}$ de altura e que ainda mostra as marcas do antigo nível do solo próximas a partes mais altas da gruta. Uma série de cacos de calcita (mineral de composição $\mathrm{CaCO}_{3}$ ) quebrados a amontoados nas laterais dos condutos e salões da caverna demonstram a ampliação de espaços ou até mesmo a abertura de corredores antes não descritos no mapa desenhado por Brandt. ${ }^{68} \mathrm{~A}$ nota de Lund ainda traz a informação de que o trabalho de extração do salitre ocorria naquela região por cerca de meio século e que pode ter permanecido ainda por mais tempo.

Fato comum entre Vieira Couto, Eschwege e Peter Lund é que todos lamentam a condição da extração do salitre nas cavernas mineiras. Todos os três, cada um a seu tempo, concordam, sem nunca terem se encontrado, que a extração do salitre poderia ser renovada desde que toda a terra retirada e trabalhada fosse mais uma vez reconduzida ao interior das cavidades.

Na metade do século XIX, as referências sobre o salitre e seus métodos de extração em Minas Gerais são escassas, o que pode se dever ao fato do desimpedimento da importação do mineral de grandes países produtores como a Índia, mas também pode ser reflexo direto das Revoltas Liberais ocorridas em Minas e São Paulo em 1842 que aumentavam ainda mais o rigor aos produtores de salitre pelo medo de insurgências contra o império.
Outro importante nome da história das ciências no Brasil (e que também concordava que o salitre podia ser uma fonte renovável nas cavernas caso a terra submetida a extração do salitre fosse misturada a terra vegetal) é Emmanuel Liais. Após conhecer Minas Gerais em 1852 o astrônomo francês efetuou um minucioso trabalho de mapeamento do Rio das Velhas e seus entornos, indicando que

o salitre, sem dúvida, ainda é formado atualmente nas cavernas. A experiência tem mostrado que se houver a reinserção de novas terras vegetais nas cavernas de onde foi extraído para remover o sal, uma nova produção de salitre pode ser realizada geralmente em quantidades notáveis neste novo solo, mesmo após um certo número de anos. Estas terras contêm de fato o potássio, e ao mesmo pela decomposição que ocorre na massa como resultado de substâncias orgânicas que eles contêm, assim como em salitreiras artificiais. É evidente que, num país onde a água, ligeiramente nitrada sob a influência de tempestades, se infiltrar gota a gota nas cavernas, e o ar pode se encontrar com traços do vapor nitrosos, a nitrificação deve operar com facilidade e abundância, como evidenciado pela experiência do descanso. Eu não vou me deter ainda mais para explicar esta nitrificação, mas eu não posso deixar de chamar a atenção para a falta de previsão dos habitantes dessas regiões, que estão destruindo os depósitos de salitre, removendo a terra fora das cavidades sem ter o cuidado, depois de removê-lo, de introduzir novas terras destinado a se tornar no futuro uma nova fonte de riqueza. A este respeito, o governo brasileiro faria bem por submeter um regulamento para a extração do nitro das cavernas; e também seria de grande interesse para a ciência recomendar a conservação de ossos removidos a partir desses ossuários, assim como trazer um hábil zoólogo e paleontólogo de tempos em tempos nos depósitos de ossos para recolher as peças mais interessantes para a ciência. ${ }^{69}$

Sem dar maiores detalhes, Liais concorda com Accioly que em sua memória atribuía a formação do 'ácido nitroso' (ácido nítrico, $\mathrm{HNO}_{3}$ ) na atmosfera "sob influência de tempestades". Ambos estão de acordo com participação de relâmpagos na oxidação do nitrogênio, assim como fora demonstrado por Cavendish. Nota-se ainda uma preocupação com a forma de extração de salitre que ainda devia ocorrer durante sua visita às cavernas das bacias dos rios São Francisco e Velhas.

O britânico Richard Burton, famoso por fazer uma viagem em agosto de 1867, iniciada a bordo de canoas que partiram de Sabará, indo depois até o oceano Atlântico no litoral nordestino. Passando através dos Rios das Velhas e São Francisco, Burton também narra a extração de salitre que ocorria nas margens de ambos os rios em Minas Gerais e na Bahia. Logo após partir de Santa Luzia em sua embarcação, o inglês menciona a extração mineral em cavernas salitreiras cujo "produto é preparado às bocas (das grutas) por um processo simples" que ele explicava em capítulos posteriores. ${ }^{70}$ Após narrar sua visita ao santuário de Bom Jesus da Lapa, já na província da Bahia, Burton explica o processo de extração de salitre e observa que:

consiste em mera lixiviação; a terra cor de chocolate, misturada com pedra, é lançada em um banguê. Este consiste, geralmente, em uma pirâmide quadrada de madeira, com a base voltada para cima, igualmente útil para extrair salitre ou lixívia. As pessoas mais pobres usam um couro, sustentado por quatro estacas, e em caso ou outro, o processo é semelhante ao da confecção da geleia. Quando submetidas à água quente, as partículas nitrosas se dirigem, devidamente 
filtradas, para um tubo, que dá para um cocho ou calham muitas vezes o fundo de uma canoa velha. A decoada, como é chamada então, é um líquido fino e esverdeado, que deve ser fervido em um tacho, muitas vezes montado em uma casa de cupim, semelhante aos usados para a confecção da rapadura. O produto é purificado, repetindo-se a operação, e aparece em colunas regulares de seis lados de uma cor branco-amarelada. O preço aqui é de seis cobres; no Alto Rio das Velhas, vende-se por $10 \$ 000$ a arroba.

Nesse trecho de seu livro, Burton afirma não ter tido a chance de analisar o salitre por ter perdido as amostras que adquiriu. Entretanto, ele afirma que esse produto era impuro, mas apresentava boa qualidade e era muito utilizado no sertão, não para fazer pólvora, mas sim para fins medicinais. ${ }^{70}$

O capitão Augusto Fausto de Souza (1835-1890), importante militar político e historiador carioca que chegou ao posto de Coronel antes de sua morte, ${ }^{71}$ escreveu em 1872 sua "Memória sobre a conveniência de serem explorados pelo Governo os riquíssimos jazigos naturaes de salitre existentes na Província de Minas Geraes" mesmo que provavelmente não tenha visitado a província. $\mathrm{Na}$ memória o capitão faz uma interessante comparação com os produtos importados, mas que no Brasil poderiam ser produzidos a partir de jazidas minerais (por exemplo, ferro e carvão de pedra). O Capitão afirma que

As duas principaes causas julgo que se pode attribuir este phenomeno: $1^{a}$ a falta de braços e difficuldade de transporte para a exploração desses artigos, que se achão às vezes a grandes distâncias dos centros de população; $2^{a}$ ao espírito de inércia ou falta de iniciativa que há entre nós, devido talvez à facilidade com que se pode nas cidades povoadas, ganhar os sensos necessários à vida. ${ }^{72}$

Ele confirma ainda que boa parte do salitre utilizado para produção de pólvora na fábrica de Pólvora da Estrela era originado de Minas Gerais até o ano de 1835. Após esse ano

ficou de tal sorte despensado o fabrico de salitre, que até parece que os próprios habitantes esquecerão-se de que existe esse produto entre o grande número dos que enriquecem a sua bela e opulenta Provincia.

Ainda de acordo com o capitão Fausto, a construção das estradas de ferro e a continuação de seus ramais até os locais de produção de salitre poderiam impulsionar mais uma vez a extração desse bem mineral. Isso provavelmente não aconteceu pois até o ano de 1881 as estradas de ferro ainda não alcançariam nem mesmo a capital de Minas Gerais, a cidade de Ouro Preto.

Esse mesmo ano, em 1881, foi marcado pela visita que Dom Pedro II, Imperador do Brasil, realizou à província mineira. Ao longo de sua viagem ele vai detalhando em seu diário dados sobre geologia, rios, população ou mesmo outras curiosidades. D. Pedro II tem como "companheiro" o livro de Saint-Hilaire e dele vai obtendo informações que às vezes contradizem o que observava. Um dos maiores interesses do imperador em sua viagem a Minas era de conhecer o paleontólogo dinamarquês, Peter Lund, que morreu no ano anterior a sua viagem. Mesmo assim Pedro II visita a cidade de Lagoa Santa e conhece algumas cavernas de onde se extraía o salitre. No dia 08 de abril de 1881 ele escreve em seu diário: ${ }^{73}$

Estive na gruta 2 horas tendo almoçado antes fora dela debaixo das árvores. A agua era salitrosa. Encontrei aí um Manuel Simão dos Reis que disse-me como Lund em companhia encontrara o esqueleto na gruta da Escrevania. Simão tirava salitre e depois de achar os dedos dos pés e o resto do esqueleto procurando mais dera com o crânio. A camada de salitre é relativamente moderna.

É bem provável que, a essa altura, o salitre já não levantasse interesse como matéria prima para a pólvora e que talvez pequenos exploradores já utilizassem o nitrato para uso como fertilizante agrícola ou para outros fins que não necessitassem maiores transformações.

A Lapa das Perobas, que recebeu a visita de Peter Lund em 1835 também foi visitada no final do século XIX por outro importante personagem do cenário de Minas Gerais e, especificamente, de Belo Horizonte. Carlos Leopoldo Prates (1864-?) foi um dos engenheiros responsáveis pelo projeto da capital mineira depois de se formar em Engenharia de "Minas c/ regalias de Civil" pela Escola de Minas de Ouro Preto em $1890 .{ }^{74}$ No início de sua carreira, em 1891, foi enviado ao vale do rio das Velhas para inspecionar a viabilidade de produção do nitrato depois de ter sido contratado pela "Companhia brasileira de salitraes, terras e construcções" com sede no Rio de Janeiro. Sua missão seria

installar tantas officinas para a extracção do salitre, quantas fossem necessárias ao aproveitamento das que encontrasse no caso de serem lavradas. ${ }^{75}$

Uma dessas primeiras fábricas, ou "officinas", seria instaurada na fazenda Peroba de Cima. No entanto, mesmo pesquisando em mais de 20 cavernas, Prates não achou riqueza alguma de terra salitrosa que compensasse o esforço da implantação da fábrica. Contudo, a descrição mais interessante é a que Carlos Prates faz de uma das grandes cavernas que visita em que aponta que

Na mais extensa d'essas grutas, disposta em andares, se encontram escadas, umas feitas de paus roliços amarrados em cipó e outras em pranchões de madeira serrada, e todas ellas em tão perfeito estado que me serviram para o acesso aos diversos andares. ${ }^{75}$

A descrição que faz sobre essa cavidade concorda com o que ainda pode se notar no interior de uma cavidade, situada na Serra do Baldim, em Jequitibá - MG, cujas escadas, utensílios de madeira e marcas de instrumentos de perfuração ainda são mantidos no interior da gruta. ${ }^{76}$ Prates conta ainda que no entorno de algumas dessas cavernas pequenos aglomerados sociais foram criados com intento de explorar o sal da terra e que dele, através de práticas rudimentares de lixiviação e cristalização dos nitratos, conseguiam tirar sustento, "conseguindo até recursos modestos para o futuro dos seus".

Por fim, apesar do belo trabalho descritivo das atividades que realizou, Carlos Prates conclui que não haveria salitre em abundância que compensasse a instalação de nenhum empreendimento minerário naquelas regiões dada a exaustão de terras nitrosas e de seu precioso sal.

\section{EQUIPAMENTOS E TÉCNICAS UTILIZADOS NA EXTRAÇÃO DO SALITRE DAS CAVIDADES}

Não são facilmente encontradas ilustrações que indicam a forma utilizada pelos exploradores de salitre do século XVIII. Entretanto, apesar de separados por milhares de quilômetros, a extração do salitre de cavernas no Brasil não parece ter se diferenciado muito do que se aplicou como técnica na Europa ou no interior dos Estados Unidos. 
A imagem a seguir (Figura 6) ilustra a produção de salitre na França pós-revolucionária cuja imagem, disponível no site Paris Musées traz os seguintes dizeres

Fabricação de salitre: Como se temia faltar pólvora para se fornecer aos quatorze exércitos que a França tinha de pé, convidaram-se os cidadãos a extrair das cavernas o salitre, que elas poderiam produzir. Esta operação se fez com tanto zelo e prontidão, que em muito pouco tempo ele foi obtido suficientemente para não mais se temer que faltasse, devido a guerra durar ainda vinte anos.

A figura ilustra situação semelhante à que narraram os naturalistas que visitaram o interior de Minas. $\mathrm{O}$ trabalho dos mineradores envolvidos na extração do salitre envolvia a percolação da terra salitrosa retirada de cavernas com a passagem de água em troncos ocos de árvores (ou em barris como na Figura 6), que estão suportados por uma pequena plataforma. Abaixo dos barris e plataformas eram usados recipientes menores que coletavam a água percolada que extrai as partes solúveis, que eram fervidas em um tacho para a evaporação da água e cristalização do salitre.

As primeiras pistas encontradas sobre a forma de como se conduziam as extrações do nitrato das terras subterrâneas em Minas Gerais no período analisado são narradas na Carta de Bernardo de Lorena, governador da capitania (ver Material Suplementar). O documento lista os equipamentos que haviam sido utilizados na mineração em Montes Altos: almocafres e alavancas para a separação e trituração da terra salitrosa; rolos de cobre e estanho, metais esses que provavelmente foram importados da Europa, que devem ter sido utilizados na confecção de barris ou moldados na forma de tachos e caldeirões para fervura de misturas de terra, da água e cristalização do material.

Já em 1818, Spix e Martius narram o "muito simples preparo do salitre" que os dois presenciaram em Minas Gerais nas vizinhanças de Formigas, atual Montes Claros, que se extraía de dentro de algumas cavernas. Os dois afirmam que milhares de arrobas do minério foram removidos das grutas que continham terra avermelhada muito fina. Os alemães tinham mais interesse nos vestígios paleontológicos que poderiam encontrar, mas fazem uma descrição sobre a forma como se extraíra o salitre naquelas vizinhanças:

Lava-se a terra com agua e concentra-se a lixívia por evaporação; mistura-se-lhe, depois, lixívia comum de potassa, e despeja-se, uma vez decantando o forte sedimento e clarificado o líquido, numa grande gamela de pau, onde o salitre aparece em cristais bastante puros. Para novas lixivias da terra, utiliza-se a lixívia-mãe que restar, e recomeça-se de novo a mesma operação. ${ }^{77}$

A lixiviação, técnica narrada pelos naturalistas, nada mais é quimicamente que a extração de substâncias sólidas solúveis por percolação de água (nesse caso) através de um material poroso. Essa técnica deve solubilizar os nitratos de potássio, de cálcio e magnésio, predominantemente presentes na solução, aos quais é adicionada a outra lixívia. Esta segunda era obtida da percolação de água através de cinzas de madeira, ricas em óxidos, hidróxidos e carbonatos de sódio e potássio. Ambas as soluções eram fervidas juntas - é provável que a simples "evaporação" fosse um processo demorado e aqui talvez exista ou um erro de interpretação dos alemães que não deixam claro terem assistido o processo ou ainda de uma tradução errônea para o

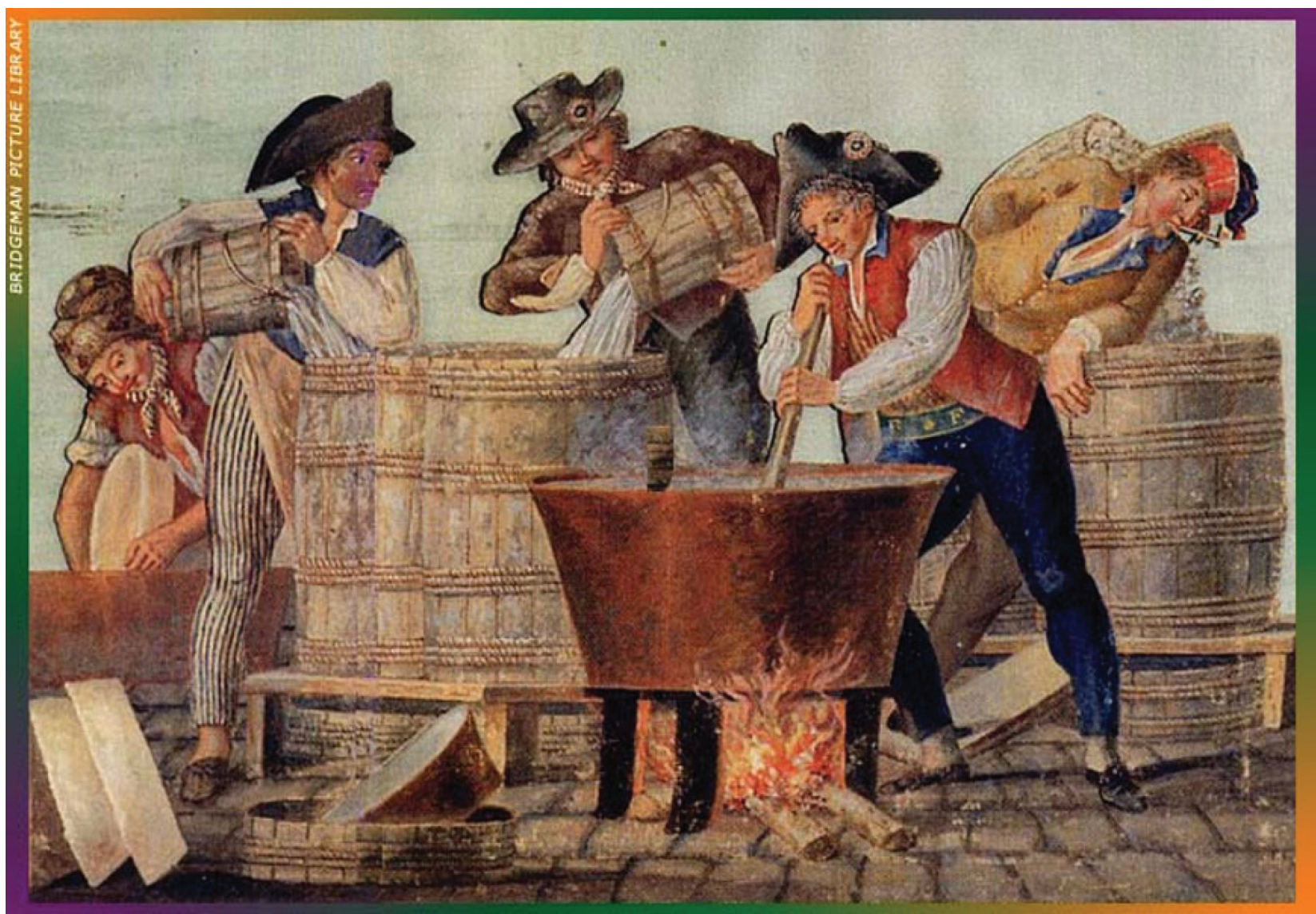

Figura 6. Produção francesa de salitre na virada dos séculos XVIII para XIX (Photographie d'un dessin de Jean-Baptiste Lesueur, Fabrication du salpêtre, disponivel em http://parismuseescollections.paris.fr/en/node/363901\#infos-principales) 
português - para concentração dos solutos. Durante a mistura, a reação de formação de carbonato de cálcio (Equação 1), que deve ocorrer a quente, pode ser responsável pela formação do "forte sedimento" de baixíssima solubilidade em água:

$\mathrm{Ca}\left(\mathrm{NO}_{3}\right)_{2 \text { (aq) }}+\mathrm{K}_{2} \mathrm{CO}_{3 \text { (aq) }} \rightarrow 2 \mathrm{KNO}_{3 \text { (aq) }}+\mathrm{CaCO}_{3 \text { (s) }}$ (Equação 1)

A clarificação deveria ser algum processo de filtragem grosseira de sobrenadantes da mistura, cuja interpretação do pequeno texto não é precisa (talvez uma etapa de recristalização). Para que o salitre, na forma de mistura de nitratos de sódio e potássio, fosse cristalizado, a temperatura da mistura deveria ser levemente baixada e, como descrito, devia ocorrer em gamelas de madeira. Relatos de outros viajantes chamam esse processo como o "congelamento" do salitre dada a formação de cristais a partir da solução concentrada. A nota dos alemães a respeito do salitre do norte de Minas termina ainda com a indicação que

muitos milhares de arrobas foram despachados para a Bahia e Rio de Janeiro onde a arroba custava de 4 a 5\$000, ao passo que, no lugar da exploração, se obtinha por $2 \$ 000$. Na época de nossa estada, as remessas, em sua maioria, eram feitas para a Fábrica de Pólvora do Rio de Janeiro. ${ }^{78}$

Spix e Martius estão em acordo com o que descreveu SaintHilaire $^{79}$ após sua passagem pelos mesmos distritos. Todos ilustram o fato que o escoamento do salitre produzido no interior de Minas e Bahia deixava de ser encaminhado à Cidade da Bahia para dar preferência à Fábrica do Jardim Botânico no Rio, conforme já foi discutido anteriormente neste artigo. O Rio de Janeiro, o que também corrobora o texto de Mawe, mesmo antes da vinda da Família Real já concentrava recursos financeiros e os poderes políticos da Colônia desde a transferência da capital do Nordeste para o Sudeste, ocorrida em 1763.

Após Eschwege fazer um prospecto da extração de salitre no Brasil no seu livro Pluto Brasiliensis, o alemão contribuiria sobre a forma de se extrair esse mineral, descrevendo o que observou em 1816:

Visitei as grutas calcárias de Formiga, na comarca do Rio das Mortes (...) nas operações da fábrica (de salitre) são empregados, ao todo, 10 escravos, que extraem e transportam a terra da gruta em carrinhos de mão, até onde, por meio de uma calha, ela é lançada em carros de boi. (...) A terra, em pedaços muito duro, e, em primeiro lugar, quebrada grosseiramente por meio de macetes, e, então levada às caixas de lavagem, cavadas em grossos troncos de arvore. As águas de lavagem são fervidas em 6 caldeiras, cada uma das quais mede 6 palmos de diâmetro e profundidade. A mistura alcalina é feita a parte e depois juntada as aguas de lavagem. E preparada com as cinzas das madeiras mais rijas, sobretudo a aroeira. Em uma caldeira a parte, as aguas mães são de novo fervidas e então filtradas num vaso de madeira, onde o salitre se cristaliza. Como isto se dá antes da cristalização do cloreto de sódio, aproveita-se esse tempo para tirar o resto das águas mães e preparar um sal de cozinha impuro, contendo ainda salitre. Este sal serve para a alimentação do gado que, no Brasil, geralmente não pode desenvolver-se sem o auxílio desta substância. ${ }^{80}$

O emprego de escravos é pela primeira vez levantado, pois deveria se tratar de um trabalho, além de árduo, de enorme dificuldade tanto pela escuridão, pelo transporte e pelo ambiente insalubre dos interiores de cavernas que variam sensivelmente de acordo com suas dimensões. Ali parece empregar-se a mesma forma de extração do salitre descrita por Spix e Martius com a adição das duas lixívias em separado, mas com indicação correta da extração do sal de cozinha que era outra fonte de renda para proprietários rurais voltados à criação de gado. Eschwege ainda pontua que esse salitre que ainda não estava completamente refinado "é exportado para a Real Fábrica de pólvora do Rio de Janeiro, onde alcança preço de $4 \$ 800$ a arroba. A fábrica produz anualmente cerca de 150 arrobas". O valor obtido pelo produto na capital também concorda com o descrito pelos naturalistas anteriores que indicam valor entre 4 a 5 mil réis. Eschwege acha baixo tal preço pago pelo salitre e comenta ter sido uma das causas da decadência da indústria instalada na capitania de Minas Gerais.

\section{CONSIDERAÇÕES FINAIS}

Como se pôde perceber, o salitre na capitania de Minas Gerais ou mesmo na Bahia estava disperso ao longo de toda a bacia do Rio São Francisco, alcançando regiões diferentes do nosso país, fato diferente daquele ocorrido na descoberta dos depósitos de ouro e diamantes em Minas, cujas jazidas levaram à fundação de povoações próximas umas às outras e formavam distritos minerários. As cavernas calcárias foram os locais de maior atividade extrativa uma vez que são locais propícios à formação e fixação dos nitratos, que nos ambientes externos teriam sido carreados por águas de chuvas e rios ou incorporados em vegetais e microrganismos. A grande diversidade e quantidade de cavidades na bacia do São Francisco, de formação geológica comum, era constante alvo de prospecção mineral na busca por salitre. Contudo, tais nitreiras naturais estavam muito afastadas dos locais de beneficiamento (as fábricas de pólvora) ou de consumo, uma vez que eram guerras e conflitos os maiores "mercados" para o principal derivado do salitre. A produção desse bem mineral deve ainda ter acompanhado tendências de consumo, à medida que conflitos (como a Guerra do Paraguai) eram iniciados ou se intensificavam, fato que aumentava os valores e comércio da pólvora. Vale salientar que a pólvora era complementar às alternativas de mineração das grandes riquezas mineiras pois era utilizada como explosivo em lavras de mineração, além de encontrar utilidades de porções menores em oficinas e casas de fundição e boticas para fins medicinais.

As técnicas de identificação, exploração e exportação do salitre evoluíram a partir do norte da capitania de onde se tem as referências mais antigas de exploração das cavernas, até aparecer em referências mais recentes em regiões centrais e do sul de Minas Gerais. A exportação também parece ter inicialmente seguido em direção a Salvador, diferente do que ocorreu com o transporte de ouro e diamantes que dirigia a produção para o porto de Parati, inicialmente, e depois do Rio de Janeiro. Sem dúvida, os primeiros exploradores desse bem mineral não dispunham de tecnologias adequadas para a extração do salitre. A mineração empregada parece ter variado entre períodos e regiões diferentes, logo podese supor grande variação na pureza e qualidade do produto obtido, que nem sempre deveria ganhar os mercados das fábricas, mas sim alimentar o tráfico do comércio e indústria de pólvora de pequenos produtores espalhados pela região. Era grande o interesse do governo pela soberania e controle estratégico da produção do salitre. Daí, mesmo frente ao contrabando, o governo tentou tomar o controle e/ou conhecer locais e técnicas para a produção, refino e transporte desse material até os locais de beneficiamento. Esse interesse é traduzido pelo envio de especialistas com formação científica, que conseguiam reunir tropas e mantimentos para viagens e incursões de conquistas no interior no Brasil.

Importantes nomes da mineralogia e da química, como José Bonifácio de Andrada, Joaquim Velozo de Miranda, José Accioly 
Bitencourt, João Manso Pereira, José Vieira Couto e W. L. (Barão) von Eschwege estiveram inicialmente ligados às questões da produção em campo do salitre (natural ou artificial) ou de seu controle pelas autoridades reais. Destaca-se ainda o grande interesse pelo assunto demonstrado pelos viajantes naturalistas e outros, à medida que decorria o século XIX - Mawe, Spix e Martius, Saint-Hilaire, Richard Burton, Peter Lund e Carlos Prates - unindo os conhecimentos de cavidades e seus conteúdos de fauna e fósseis à sua extração. Mesmo indiretamente, esses grandes especialistas deixaram em seus tratados uma descrição do que ocorreu nesse capítulo da história da exploração daquele importante produto mineral.

Nessa descrição, fica claro que as experiências utilizadas para a produção do nitrato tomavam bases mais técnicas pela repetição do que já havia ocorrido em outros locais e épocas. Apesar de os naturalistas não terem descrito a produção e uso da pólvora no interior de Minas, é quase certo afirmar que a manufatura desse item deveria ser uma opção de pequenos produtores ou mesmo de grandes propriedades rurais. Esses produtores eram beneficiados pelas grandes massas de salitre produzido e enviado para a Fábrica Real. Já o valor atribuído a esse item também parece ter concorrido com o que se praticava, mais uma vez, em escala global, pois a concorrência do produto do interior de Minas, dadas as dificuldades do transporte, chegava no Rio de Janeiro com preços menos competitivos que aquele da arroba do salitre importado incialmente dos grandes depósitos da Índia ou mais tardiamente no Chile.

O fato é que o salitre exerceu e influenciou modificações profundas na forma de se encarar a produção de riquezas no Brasil Colônia e no Brasil Império. O salitre foi crucial para o processo de Independência do Brasil, pois, pelas palavras de Manuel Ferreira da Câmara Bittencourt e Sá (1762-1835):

quanto a importância de tão importante gênero [o salitre de minas] contribuiu para a nossa emancipação e não foi decerto com o salitre vindo de fora que debelaram os lusitanos na província da Bahia. ${ }^{81}$

\section{MATERIAL SUPLEMENTAR}

Carta de Bernardo José de Lorena, governador das Minas Gerais, a D. Rodrigo de Sousa Coutinho, levantando dúvida sobre salitreiras do S Francisco entre Bahia e MG (AHU_ACL_CU_005, Cx. 145, D. 21).

\section{AGRADECIMENTOS}

Os autores gostariam de agradecer a Marcos Giovanni pelo apoio em trabalhos de campo e a Débora Almeida pela confecção de figuras usadas no texto.

\section{REFERÊNCIAS BIBLIOGRÁFICAS}

1. Sobral, T. R.; Jornal de Coimbra 1816, IX, Parte I, p. 293.

2. Ferraz, M. H. M.; Quím. Nova 2000, 23, 6.

3. Idem ibidem.

4. http://www.spq.pt/sociedade/historia/biografias, acessada em dezembro 2020.

5. Lisboa, J. J.; Em Ver \& Ler; Lisboa, J. J., Moretto, M., eds.; Ed. Giordano Ltda: São Paulo, 1994, p. 12, Cap. Descripção curiosa das Principaes producções, rios, e animaes do Brazil, principalmente da Capitania de Minas Geraes.

6. Idem, p. 50.

7. Ivo, I. P.; Tese de Doutorado, Universidade Federal de Minas Gerais, Brasil, 2009.

8. Annaes do Arquivo Público da Bahia 1921, V. XXIV, p. 35.
9. Varnhagen, F. A.; História Geral do Brazil - Tomo Segundo. E. e H. Laemmert: 1857. p. 137.

10. Santos, J. F.; Memórias do Districto Diamantino da Comarca do Serro Frio (Província de Minas Geraes) pelo Dr. Joaquim Felicio dos Santos - nova edição, com um estudo biográfico de Nazareth Menezes. Livraria Castilho: Rio de Janeiro, 1924. p. 127.

11. h t t p://acervo.redememoria.bn.br/rede Memoria/ handle/20.500.12156.2/301407, acessada em dezembro de 2020.

12. h t t p : / / a cervo.redememoria.bn.br/redeMemoria/ handle/20.500.12156.2/301399, acessada em dezembro de 2020.

13. h t t p : / / a cervo.redememoria.bn.br/rede Memoria/ handle/20.500.12156.2/301396, acessada em dezembro de 2020.

14. http://purl.pt/856, acessada em dezembro de 2020.

15. Spix, J. B.; Martius, C. F. P. Em Viagem pelo Brasil: 1817-1820, Lahmeyer, L. F., ed.; Trad. Ed. Itatiaia: Belo Horizonte. 1981. p. 125.

16. Tasso, M. A. L.; Tese de Doutorado, da Universidade Estadual Paulista Júlio de Mesquita Filho, Brasil, 2012.

17. AHU, caixa 152, doc. 36, código 11647, 1800.

18. Owen, W.; A new and complete Dictionary of Arts and Sciences. Second Edition, V. III. Londres, 1764. p. 2252.

19. Accioly, J. de S. B.; Memória, sobre a viagem do Terreno Nitroso, Biblioteca Nacional, Manuscritos - 11. 2.014. 1816

20. Accioly, J. de S. B.; O Auxiliador da Industria Nacional, Sociedade Auxiliadora da Indústria Nacional 1845, 13. p. 85.

21. Accioly, J. de S. B.; op. cit.

22. Vita, S.; Luna, F.; Teixeira, S.; Quím. Nova 2007, 30, 1381.

23. Cavendish, H.; Philos. Trans. R. Soc. London 1788, 78, 261.

24. Santos, J. F.; Op. cit., p. 127.

25. Idem, pp. 128-129.

26. Idem, p. 129.

27. Ivo, I. P. (2009) apud Santos, O. F.; Dissertação de Mestrado, Universidade Estadual do Sudoeste da Bahia, Brasil, 2015.

28. Idem, p. 6.

29. AHU, caixa 145, doc. 21, código 11094, 1798

30. BN, II - 30.31.042. Carta de Apresentação de Joaquim Velozo escrita por Dom Rodrigo de Souza Coutinho, 10 de novembro de 1796.

31. AHU, caixa 154, doc 36, código 11717. 1800.

32. Idem.

33. Filgueiras, C. A. L.; Origens da Química no Brasil. Ed. UNICAMP: Campinas, 2015. p. 101.

34. http://bdlb.bn.gov.br/acervo/handle/20.500.12156.3/395483, acessada em dezembro de 2020.

35. http://objdigital.bn.br/objdigital2/acervo_digital/div_manuscritos/ mss1460877/mss1460877.pdf, acessada em dezembro de 2020.

36. Santos, J. F.; Op. cit., p. 308.

37. AHU. Documentos da Bahia no. 3529 e 3586. Enc. XIV - sem data, provavelmente anterior a 1800 .

38. APM, Carta das nitrateiras de Monte Rodrigo. Mapa manuscrito, feito à nanquim, colorido, localizando a região da barra da Paraúna, as nitrateiras de Monte Rodrigo (hoje serra da pancada), fazendas e o arraial. APM - Fundo Seção Colonial (secretaria de Governo da Capitania) - SC. Sem data.

39. APM, Mapa manuscrito, feito à nanquim, colorido, localizando a região da barra da Paraúna, as nitrateiras de Monte Rodrigo (hoje serra da pancada), fazendas e o arraial. Fundo Seção Colonial (Secretaria de Governo da Capitania), ca. 1800.

40. Couto, J. V.; Memoria sobre as salitreiras naturaes de Monte Rodrigo: maneira de as auxiliar por meio de artificiaes; refinaria do nitrato de potassa, ou salitre, Impressão Régia: Rio de Janeiro. 1809. p. VI.

41. Silva, C. P.; O desvendar do grande livro da natureza: um estudo da obra do mineralogista José Vieira Couto, 1798-1805, Annablume: São Paulo, 2002.

42. Couto, J. V.; Op. cit., p. 9. 
43. Idem, p. 12.

44. Idem, ibidem.

45. Idem, p. 22.

46. Pessoa, J. M. C. Memória sobre o nitro, e utilidades, que delle se podem tirar. Memórias Econômicas da Academia Real das Sciencias de Lisboa. Typographia da Academia Real das Sciencias, IV, 1812. p. 203.

47. Hill, C. A.; Natl. Speleol. Soc. Bull. 1981, 43, 110.

48. Couto, J. V.; Op. cit., p. 12.

49. Idem, p. 13.

50. http://www.icmbio.gov.br/cecav/canie.html, acessado em dezembro de 2020.

51. Couto, J. V.; Memoria sobre as salitreiras naturaes de Monte Rodrigo... Op. cit., p. 14.

52. Silva, C. P.; Tese de doutorado, Universidade Estadual de Capinas, Brasil, 2004.

53. Vandelli, D. Viagens Filosóficas ou Dissertação sobre as importantes regras que o Filósofo Naturalista nas suas peregrinações deve principalmente observar; Apud: Silva, C. P.; Op. cit. p. 43.

54. AHU, caixa 147, doc. 3, 1799.

55. Idem.

56. Couto, J. V.; Op. cit., p. 17.

57. Mawe, J.; Travels in the interior of Brazil, particularly in the gold and Diamonds districts of the country. Longman, Hurst, Rees, Orme and Brown, Paternoster-Row: London, 1812. p. 270.

58. APM, SG-Cx. 75, doc. 68, 1808.

59. APM, Mapa das salitreiras naturais de Linhares na mata do Distrito da Formiga vertentes do rio de São Francisco, 1810.

60. Notícia. Idade d'Ouro do Brazil. No. 5 de 17 de Janeiro de 1812. p. 4. Rio de Janeiro.

61. Edital. A Gazeta do Rio de Janeiro, ed. 63 de 7 de agosto de 1813. p. 4

62. Eschwege, W. L.; Pluto Brasiliensis, Ed. Itatiaia: Belo Horizonte, 1979. p. 191.

63. Mattos, A.; O sábio Dr. Lund e a pre-Historia Americana (Apontamentos para um estudo histórico e biográfico), Imprensa Oficial Minas Gerais: Belo Horizonte, 1930
64. Holten, B.; Sterll, M.; P. W. LUND e as grutas com ossos em Lagoa Santa, Ed. UFMG: Belo Horizonte, 2011.

65. Holten, B., Sterll, M.; Fjeldsa, J.; O Artista Desaparecido - P. W. Lund e P. A. Brandt no Brasil, Ed. UFMG: Belo Horizonte, 2012.

66. Idem, p. 215.

67. Idem, p. 216.

68. Santos, P. V. S.; Faria, L. E.; Lima, G. C.; Carmo, D. M.; Moreira, B. H. M.; Perini, P. C. D Anais do Congresso Brasileiro de Espeleologia, Eldorado, Brasil, 2015.

69. Liais, E. Climats, Géologie, Faune et Géographie Botanique du Brésil, Garnier Frères, Libraires-Éditeurs: Paris, 1872. p. 176.

70. Burton, R.; Explorations of the Highlands of the Brazil, V. II, Tinsley Brothers: London, 1869. p. 290.

71. Anais da Câmara dos Deputados, Volume 4. Departamento de Imprensa Nacional: Rio de Janeiro, 1894.

72. Arquivo Nacional, Cod. 807, V. 14, fl. 137-141.

73. Bediaga, B.; Diário do Imperador D. Pedro II; Bediaga, B.; org.; Museu Imperial: Petrópolis, 1999.

74. Lemos, P.; A história da Escola de Minas; Ed. Graphar: Ouro Preto, 2012.

75. Prates, C.; Revista Industrial de Minas Geraes; Imprensa Official do Estado de Minas Geraes: Belo Horizonte, 15 de Julho de 1894. pp. 246 (n. 10) e 275 (n. 11).

76. Faria, L. E.; Filgueiras, C. A. L.; Anais do Congresso Brasileiro de Espeleologia, Bonito, Brasil 2019.

77. Spix, J; Martius, C. F.; Op. cit., p. 81.

78. Idem, ibidem.

79. Saint-Hillaire, A.; Viagem pelo Distrito dos Diamantes e litoral do Brasil, Ed. Itatiaia: São Paulo, 1974. p. 29.

80. Eschwege, W. L.; Op. cit., p. 193.

81. Mendonça, M. C.; O intendente Câmara-Manuel Ferreira da Câmara Bittencourt e Sá, Intendente Geral das Minas e dos Diamantes (17641835), Cia. Ed. Nacional: São Paulo. 1958. p. 14 